San Jose State University

SJSU ScholarWorks

Master's Theses

Master's Theses and Graduate Research

Summer 2013

\title{
The Prevalence of the Uncultivated Bacterium TM7A in Human Subgingival Plaque
}

Jamsheed Adrian Ghadiri

San Jose State University

Follow this and additional works at: https://scholarworks.sjsu.edu/etd_theses

\section{Recommended Citation}

Ghadiri, Jamsheed Adrian, "The Prevalence of the Uncultivated Bacterium TM7A in Human Subgingival Plaque" (2013). Master's Theses. 4338.

DOI: https://doi.org/10.31979/etd.e9uk-me5h

https://scholarworks.sjsu.edu/etd_theses/4338

This Thesis is brought to you for free and open access by the Master's Theses and Graduate Research at SJSU ScholarWorks. It has been accepted for inclusion in Master's Theses by an authorized administrator of SJSU ScholarWorks. For more information, please contact scholarworks@sjsu.edu. 


\title{
THE PREVALENCE OF THE UNCULTIVATED BACTERIUM TM7A IN HUMAN SUBGINGIVAL PLAQUE
}

\author{
A Thesis \\ Presented to \\ The Faculty of the Department of Biological Sciences \\ San Jose State University \\ In Partial Fulfillment \\ Of the Requirements for the Degree \\ Masters of Science
}

by

Jamsheed A. Ghadiri

August 2013 
(C) 2013

Jamsheed Ghadiri

ALL RIGHTS RESERVED 
The Designated Thesis Committee Approves the Thesis Titled

THE PREVALENCE OF THE UNCULTIVATED BACTERIUM TM7a IN HUMAN SUBGINGIVAL PLAQUE

by

Jamsheed Ghadiri

APPROVED FOR THE DEPARTMENT OF BIOLOGICAL SCIENCES

SAN JOSE STATE UNIVERSITY

August 2013

Dr. Cleber Ouverney

Department of Biological Sciences

Dr. Sabine Rech

Department of Biological Sciences

Dr. Elizabeth Skorvan

Department of Biological Sciences 


\section{ABSTRACT}

\section{THE PREVALENCE OF TM7a IN HUMAN SUBGINGIVAL PLAQUE by Jamsheed Ghadiri}

Most bacteria are yet to be cultivated, and some uncultivated bacteria have been associated with human diseases. TM7, an uncultivated candidate division of bacteria, has been recently associated with periodontitis, a disease if left untreated causes tooth degradation and gum decay. A subgroup of TM7, known as TM7a, has been found in both human samples and activated wastewater. TM7a from these two locations are as high as $99.7 \%$ similar by $16 \mathrm{~S}$ rRNA gene sequence analysis, leading researchers to believe both TM7a strains are very similar functionally. TM7a has been extensively studied in activated wastewater. However, little is known of its prevalence in the human oral cavity. This research surveyed for the first time the prevalence of TM7a in human subgingival plaque by using a quantitative PCR assay (qPCR) optimized for this study. The oral cavities of six healthy individuals were sampled. A total of 34 subgingival plaque samples were collected from $5-6$ teeth per patient. It was determined by qPCR that TM7a was present in five of six (83\%) patients and in 22 of $34(64.7 \%)$ samples. The average abundance of TM7a in the human oral cavity was $3.36 \times 10^{7} \pm 2.53 \times 10^{6}$ cells g ${ }^{-1}$ and comprised $2.88 \times 10^{-1} \% \pm 2.16 \times 10^{-1} \%-1.00 \times 10^{-3} \% \pm 8.65 \times 10^{-4} \%$ total bacteria. TM7a was also found to be significantly more abundant in plaques collected from the facial sites $(p<0.0005)$, and in posterior sites $(p<0.05)$. These data suggest that the prevalence of TM7a is dynamic in the human oral cavity and provides the basis for a potential large-scale study to quantify TM7a in a population. 


\section{ACKNOWLEDGMENTS}

It would not have been possible to write this thesis without the help and support of the exceptional people around me, to only some will it be possible to give mention here.

Above all, I would like to thank the love of my life Ruby for her unequivocal personal support and great patience. My family, for their support throughout my life, for which my mere expression of thanks does not suffice.

This thesis would not have been possible without the guidance, support, and patience of my principal investigator, Dr. Cleber Ouverney. His guidance both in and out of the lab has been invaluable both academically and personally, for which I am extremely grateful.

I would also like to acknowledge Dr. Karen Singmaster for her continual advice and support.

I thank Dr. Sabine Rech and Dr. Elizabeth Skorvan for taking time from their busy schedules to review my thesis. I would also like to thank Dr. John Boothby and Dr. Michael Sneary for the opportunity to instruct microbiology laboratories. I get a great sense of accomplishment every time a former student expresses their thanks.

A huge debt is owed to the National Institute of Health grants SCORE (1SC3GM0822 91-01) and RISE (1SC3GM0822 91-01) for funding most expenses linked to this work. I would also like to thank the SJSU Department of Biological Sciences (Glen and Martha Vargas Scholarship); this funding was pivotal for the completion of this thesis. 
I would like to thank Dr. Olga Khevsurishvili, DDS for collecting the samples used in this study

Last but certainly not least, I would like to express my gratitude and thanks to all my lab mates both current and past for the outstanding atmosphere they provided in the laboratory. I would like to acknowledge Iana Elledge and my brother Farsheed Ghadiri for assisting me in this project.

To my brother Farsheed, it has been an honor and a privilege to work with you, words cannot express how proud I am to have been able to assist and watch you grow as a researcher. 


\section{Table of Contents}

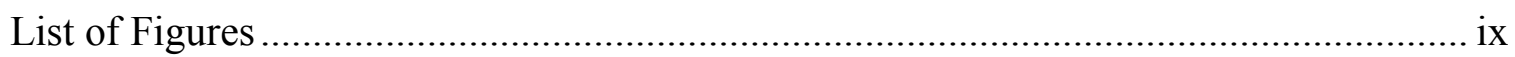

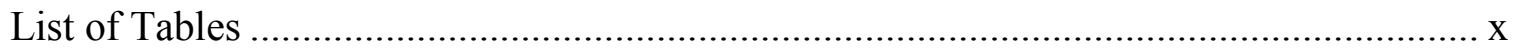

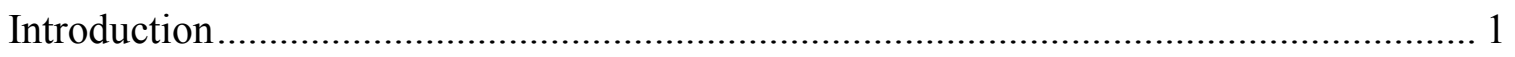

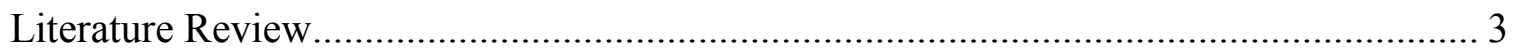

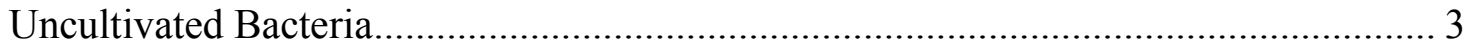

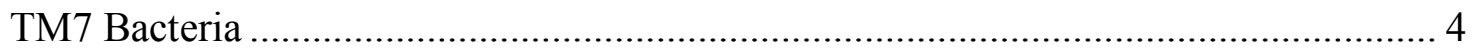

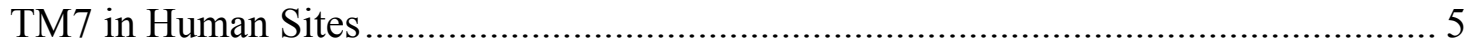

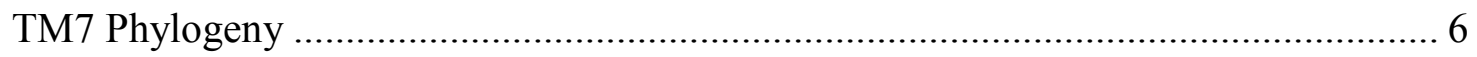

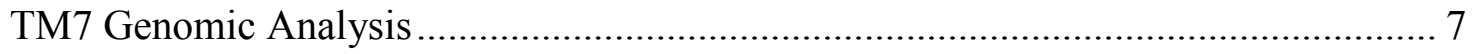

Molecular Methods for the Detection and Quantification of TM7 ............................. 8

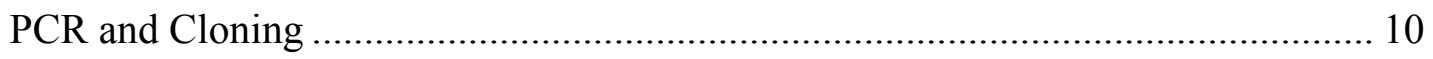

16S rRNA Sequencing and Phylogenetic Analysis .......................................... 10

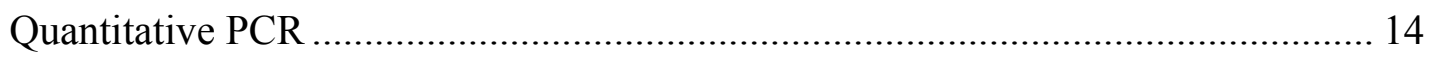

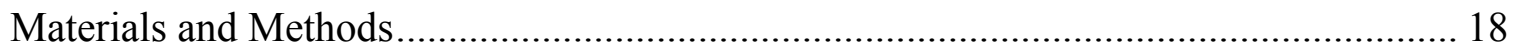

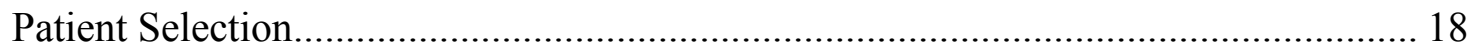

Sample Collection and Processing ........................................................................ 18

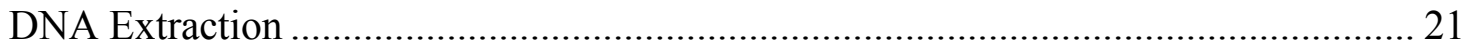

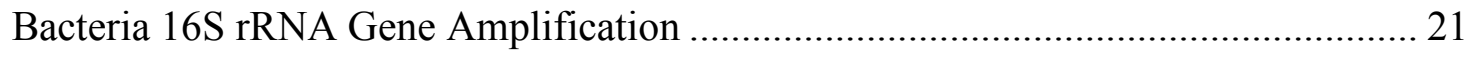




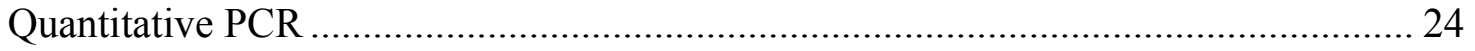

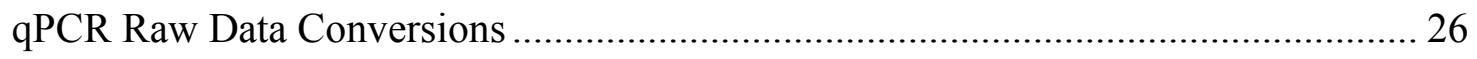

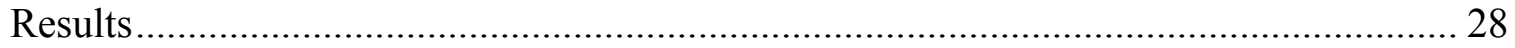

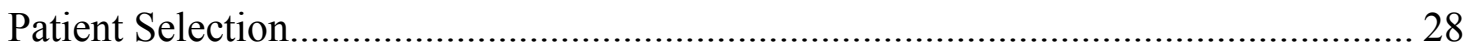

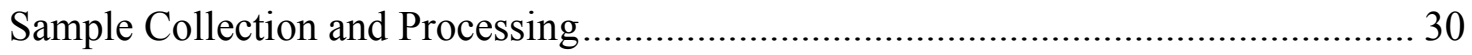

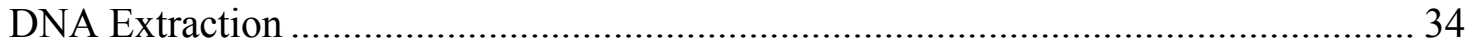

Bacteria 16S rRNA Gene Amplification ............................................................. 36

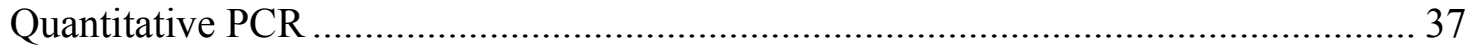

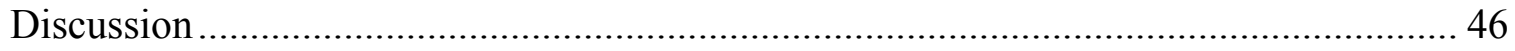

Assay to Target TM7a in Human Subgingival Plaque .......................................... 46

Quantification of TM7 and TM7a in Human Subgingival Plaque ........................... 47

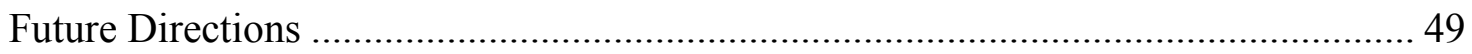

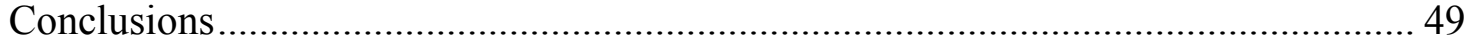

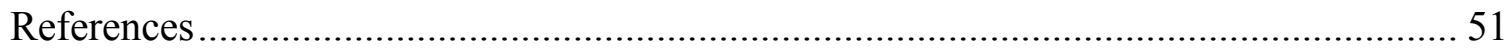




\section{List of Figures}

Figure 1. Use of probe to measure periodontal pocket fepth (nidcr.nig.gov, 2013) ........ 19

Figure 2. Universal tooth numbering chart (Dentalfearcentral, 2013)................................ 20

Figure 3. Calculation for converting raw qPCR data, rRNA gene copy number/ $\mu 1$, to cells/g of pelleted oral plaque

Figure 4. PCR screening results from extracted genomic DNA using BAC 8F and

BAC 515R 36

Figure 5. Average number of total bacteria, TM7, and TM7a in human oral subgingival plaque

Figure 6. Average number (cells $\mathrm{g}^{-1}$ ) of TM7a cells from Facial and Lingual

plaque samples

Figure 7. Average number of TM cells (cells g ${ }^{-1}$ ) from Anterior or Posterior plaque samples.

Figure 8. Average number of TM7a cells (cells $\mathrm{g}^{-1}$ ) from Healthy or Gingival

plaque samples 45 


\section{List of Tables}

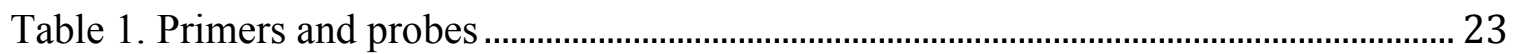

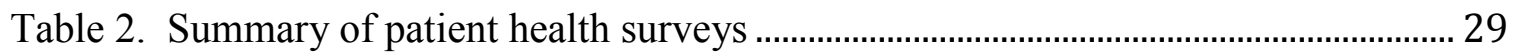

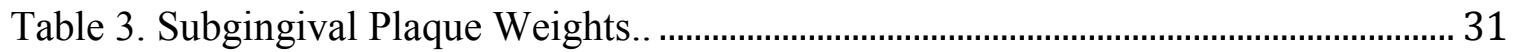

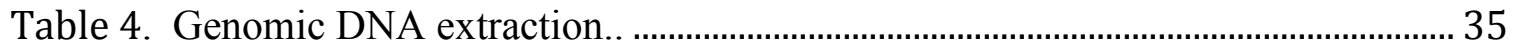

Table 5. Amplification efficiency values from qPCR experiments.......................................38

Table 6. Quantification and relative abundance of TM7a based on qPCR assay............. 41 


\section{Introduction}

The vast majority of the bacterial diversity known today consists of strains that cannot yet be grown in pure culture under laboratory conditions. Since molecular techniques were first applied to identify bacteria, the number of known phylum-level lineages increased from 12 (Woese, 1987) to over 100 (Sogin, 2009), most of which are known as candidate divisions as its members are yet to be cultivated. An estimated $68 \%$

of the human oral flora is composed of uncultured bacteria (Dewhirst et al. 2010). Some of these uncultivated bacteria have been associated with human oral disease, promoting an increased effort to understand their role in this infected site (Brinig et al., 2003; Lawson et al., 1998).

The candidate division TM7 has been detected in a variety of organisms and environmental sources including garden soil, fresh and marine water, activated wastewater (Dinis et al., 2011), canines (Dewhirst et al., 2012), and humans (Brinig et al., 2003; Dewhirst et al., 2010; Dinis et al. 2011). In humans, TM7 has been associated with the human oral disease, periodontitis, a disease that if left untreated causes tooth and gum decay (Brinig et al., 2003).

Recently, a subgroup of TM7 known as TM7a was detected on human skin and in the oral cavity. Interestingly, in 2011, TM7a was also detected in activated wastewater in San Jose, CA (Dinis et al., 2011). In that study, it was determined that the similarity 
between human oral TM7a and wastewater TM7a was $99.7 \%$ based on $16 \mathrm{~S}$ rDNA gene sequence analysis. However, TM7a has not been quantified in the human oral cavity.

In this pilot study, I quantified and determined the prevalence of TM7a in the human oral cavity. The oral cavities of six healthy individuals were sampled. A total of 34 subgingival plaque samples were collected from $5-6$ teeth per patient. Quantification of TM7a was performed using an optimized assay I adapted from Dinis et al. (2011) to understand the prevalence of TM7a in human subgingival plaque. 


\section{Literature Review}

\section{Uncultivated Bacteria}

In the late 1970s, Carl Woese used molecular techniques to redefine the tree of life (Woese, 1987). Relying on conserved genes (e.g., the small subunit of the ribosomal gene, referred to here either as $16 \mathrm{~S}$ rDNA or $16 \mathrm{~S}$ rRNA gene), he discovered a clear distinction within prokaryotes where the kingdom was split into two domains: Archaea and Eubacteria. In subsequent years, the 16S rRNA gene became the standard marker to identify bacteria, due to its conserved nature and ideal length for PCR (Lane, 1991). In the 1990s, researchers developed universal primers to target the 16S rRNA gene based on known sequencing data (Lane, 1991). These universal bacterial primers have been utilized to target bacteria within various samples sites. Since their inception, the number of known bacterial phyla has been increased from 12 (Woese, 1987) to over 100 (Sogin, 2009). As new bacterial domains were discovered, so were the number of phyla represented only by uncultured bacteria. These phyla are known as "candidate divisions" as there are no known cultured representatives and their existence is solely based on $16 \mathrm{~S}$ rRNA gene studies (Hugenholtz et al., 1998). Over 99\% of bacteria remain uncultivated (Hugenholtz et al., 1998; Rappé and Giovannoni, 2003). Many of these bacteria thrive in mixed microbial communities with diverse metabolic byproducts and complex microbial interactions, which have proven difficult to replicate in culturing media (Lewis et al., 2010; Schmidt and Konopka, 2009). Furthermore, some uncultivated bacteria have been associated with human diseases, such as gastroenteritis and periodontitis, pushing the 
effort to cultivate these bacteria in order to understand their role in infected sites and mixed microbial communities (Brinig et al., 2003; Lawson et al., 1998).

\section{TM7 Bacteria}

The candidate division TM7 is one of the most extensively studied uncultivated divisions yet still contains no cultured representatives. TM7 was first discovered in a German peat bog by targeting the 16S rRNA gene (Hugenholtz et al., 2001). In that study, the name TM7 was derived from the nomenclature used to identify sequence clones. TM7 stood for: Torf, mittlere Schicht, or peat, middle layer, clone number 7, from which the division took its name. Further studies revealed TM7's ubiquitous nature in the environment, having been found in environmental sites including garden soil, fresh and marine water, and activated wastewater (Hugenholtz et al., 2001; Dinis et al. 2011). TM7 has also been found in organisms, including marine sponges (Hardoim et al., 2009), canines (Dewhirst et al., 2012), termites (Hugenholtz et al., 2001), and humans (Brinig et al., 2003; Dinis et al., 2011). Fluorescent in situ hybridization (FISH) observations have characterized the morphologies of TM7 which range from cocci, bacilli, and filaments (Ouverney et al. 2003). The size of cocci shaped TM7 cells average $0.5 \mu \mathrm{m}$ in diameter, and 1.0 to $5.0 \mu \mathrm{m}$ for individual bacilli cells (Hugenholtz et al., 2001). Transmission electron microscopy of TM7 cells has identified a cellular structure similar in composition to that of Gram-positive bacteria; consequently, it is thought that TM7 is a gram-positive bacterium (Albertsen et al. 2013; Hugenholtz et al., 2001). 


\section{TM7 in Human Sites}

In humans, TM7 has been discovered in a variety of anatomical locations including the skin, esophagus, intestine, and the oral cavity (Brinig et al., 2003; Gao et al., 2007; Kuehbacher et al., 2008; Pei et al., 2004). The most extensively studied location is within the human oral cavity, of which a subdivision of TM7, known as 'SBG1' has been associated with chronic periodontitis (Brinig et al., 2003). Periodontitis is characterized by the onset of ovular bone degradation caused by bacteria (Oliver et al., 1991). In a study by Brinig et al. (2003), SBG1 was found to exist in significantly higher abundances in periodontal patients than in healthy patients $(p<0.001$; Fisher's exact test).

Furthermore, SBG1 cells were longer in diseased sites than in healthy sites $(p=0.003$; unpaired $t$ test) (Brinig et al., 2003; Ouverney et al. 2003). In another study, TM7 was found in all 12 patients with periodontitis and only in 4 out of 9 without (Kumar et al., 2003). Due to TM7's increased prevalence in periodontal sites, TM7 is now associated with periodontitis and is it is believed that SBG1 may be necessary for the development

of biofilms in these diseased sites (Brinig et al., 2003; Kumar et al., 2003). Additionally, TM7 has been associated with cystic fibrosis, inflammatory bowel disease, and vaginosis (Fredricks et al., 2007; Guss et al., 2010; Kuehbacher et al., 2008). 


\section{TM7 Phylogeny}

Over the past decade, efforts to establish the phylogeny of TM7 based on $16 \mathrm{~S}$ rDNA sequences have been made. TM7 was first thought to contain three monophyletic subdivisions (Hugenholtz et al., 2001). However, the most recent phylogenetic representation of TM7 suggests two monophyletic subdivisions (Dinis et al., 2011). In the most recent study, Dinis et al. (2011) utilized all 255 representative TM7 sequences from the Genebank public database to create the most accurate and up-to-date phylogenetic representation of TM7 yet. Among the 255 TM7 sequences included in the Dinis et al. phylogenetic tree, 160 were classified as environmental, 53 as humanassociated, and 42 as animal (non-human) associated (Dinis et al., 2011). Humanassociated and animal-associated TM7 sequences predominantly clustered in one subdivision and environmental TM7 in the second. That suggested TM7 bacteria associated with human and animal hosts shared an evolutionary history not shared by most environmental TM7. For a few exceptions, however, some TM7 from the environment had greater homology to the human-associated TM7 than to other environmental TM7. One novel finding in that study was a clade of TM7 (called TM7a) that included sequences retrieved from wastewater and from the human oral cavity and skin (Dinis et al. 2011). TM7a from these two locations are as high as $99.7 \%$ similar based on 16S rDNA sequence comparisons (Dinis et al., 2011). Such level of percent similarity insinuates the TM7a found in wastewater and TM7a associated with humans belong to the same species. However, the prevalence and abundance of TM7a in human subgingival plaque remains unknown. 


\section{TM7 Genomic Analysis}

Beyond the 16S rRNA single gene approach, genomic sequences can provide a more in-depth analysis by defining genes that are responsible for various functions within the bacterium. Most of the metabolic and physiological data responsible for the functional understanding of many uncultivated bacteria was derived from genomic sequences. Several studies have acquired partial genomic sequences of TM7, one study was performed in the human oral cavity (Marcy et al. 2007), the other in soil (Podar et al. 2007). These studies made use of multiple displacement amplification (MDA) to amplify individual cells isolated by either microfluidic devices (Marcy et al., 2007) or via cell sorting using flow cytometry (Podar et al., 2007). In the human oral cavity, 1,474 genes were discovered from oral TM7 clone TM7a (Marcy et al., 2007). In soil, whole genome amplification recovered 670 genes from TM7 clone GTL-1 (Podar et al., 2007). Gene comparisons found that only $20 \%$ of the predicted TM7 proteins had $>60 \%$ homology to previously sequenced proteins. That means most genes from TM7 are novel, with low similarity to any other gene studied so far. Furthermore, a third $(33.3 \%)$ of the predicted TM7 proteins were less than $30 \%$ homologous to previously sequenced proteins (Marcy et al., 2007). The most recent and most complete genome of TM7 from the human oral cavity was obtained by utilizing the genomic data of TM7a as a scaffold for 454 pyrosequencing (Liu et al., 2012). This resulted in the identification of an additional 703 genes that were not recovered by Marcy et al. (2007); however, the genome is still incomplete. The most recent and most complete genome from activated wastewater was obtained by utilizing the Illumina HiSeq2000 sequencing platform (Albertsen et al., 
2013). The average TM7 genome size was determined to be $1 \mathrm{Mbp}$, which is close to the lower limit of free-living bacteria (Albertsen et al., 2013).

Protein analysis from the identified genes provides insight to the metabolic and physiological properties of TM7. Physiological properties include the $\mathrm{H}+$ anti-porter, involved in drug resistance, as well as cytochrome $\mathrm{p} 450$, which provides resistance to toxic compounds (Marcy et al., 2007). Gene products for the type IV secretion system were also present. The type IV system plays a role in the uptake of plasmids, potentially providing the cell with antibiotic resistance (Marcy et al., 2007; Albertsen et al., 2013). Type IV pili genes were discovered potentially providing the bacterium the means of adherence to endothelial cells, as well as a means to contribute in biofilm formation. Furthermore, Type IV pili are known to provide gliding motility in gram-positive bacteria, further suggesting TM7's gram-positive origin (Marcy et al., 2007; Albertsen et al. 2013). Metabolic genes discovered include those involved in: ATP synthesis, glycolysis, the tricarboxylic acid cycle, and salvage pathways (Marcy et al., 2007). However, the completed genome of TM7 in activated wastewater suggests that TM7 can only use the pentose phosphate and heterolactic fermentation pathways. (Albertsen et al. 2013)

\section{Molecular Methods for the Detection and Quantification of TM7}

TM7 bacteria account for approximately $0.3 \%$ of the total bacterial population in the human oral cavity (Brinig et al., 2003). Therefore, it is important to perform an efficient genomic DNA (gDNA) extraction to ensure the presence of such rare bacteria in the extracted sample. Furthermore, the presence of contaminants must be limited due to 
known inhibitory properties during PCR amplification of the 16S rRNA gene. For instance, contaminants in soil and wastewater such as humic acids inhibit polymerase activity. In addition, humic acids are commonly found in DNA extractions as they have a similar charge to DNA (Yeates et al., 2003). Therefore, following DNA extraction the purity of DNA must be determined using a spectrophotometer to ensure the absence of contaminants. Using a spectrophotometer, a $260 / 230 \mathrm{~nm}$ ratio above 2 indicates pure DNA, while lower values suggest the possibility of contamination by compounds such as humic acid. In addition, the $260 / 280 \mathrm{~nm}$ ratio can indicate the presence of protein contamination in the DNA extraction. A $260 / 280 \mathrm{~nm}$ value of 1.8 is indicative of pure DNA, however as the ratio increases so does the relative abundance of protein contamination (Yeates et al., 2003).

The DNeasy blood and tissue kit (Qiagen, Valencia, CA) is commonly utilized to perform genomic DNA extractions from various human anatomical sites. This kit has been successfully utilized to obtain TM7 gDNA from the oral cavity (Dinis et al., 2011). That same study used the suggested modified protocol included in the kit for grampositive bacterium as TM7 is thought to be gram-positive-like (Hugenholtz et al., 2001). The gram-positive protocol makes use of chemical means to lyse the bacterial cells. The principal component is lysozyme, which catalyzes the hydrolysis of N-acetylmuramic acid and N-acetyl-D-glucosamine residues, abundant components of the peptidoglycan cell wall of gram-positive bacteria (Mckenzie and White, 1991). The gDNA is then isolated by ethanol precipitation (Yeates et al., 2003). 


\section{PCR and Cloning}

Once pure gDNA is obtained, the $16 \mathrm{~S}$ rRNA gene is amplified using PCR, then PCR amplicons are cloned into Escherichia coli cells. TM7 16S rRNA sequences were originally obtained in 2001 in a study utilizing PCR with general bacteria primers BAC 8F and BAC 1492R (Hugenholtz et al., 2001). These general bacterial primers target a large proportion of the bacterial community (DeLong, 1992) and TM7 sequences were detected within that community. To target TM7 specifically, a TM7 primer was created known as TM7 1177R (Brinig et al., 2003). In combination, the BAC 8F and TM7 1177R primer pair has been utilized to PCR amplify TM7 16S rRNA genes, of about 1,189 base pairs, in a variety of samples (Brinig et al., 2003; Dinis et al., 2011). PCR reactions utilizing these primers was performed using Taq DNA polymerase and an annealing temperature of $64^{\circ} \mathrm{C}$ (Brinig et al., 2003). The resulting PCR products were cloned using the TOPO-TA cloning kit in combination with TOP10 chemically competent E. coli cells (Invitrogen, Carlsbad, California). The clone library generated was then screened for clones with the correct insert size $(\sim 1,189 \mathrm{bp})$ via PCR and plasmids were extracted from each positive clone.

\section{S rRNA sequencing and Phylogenetic Analysis}

BigDye sequencing methods (e.g. Sanger sequencing) have been widely used to obtain 16S rRNA gene sequences (Applied Biosystems, Foster City, California). To retrieve the entire sequence of the PCR amplicon cloned, vector-specific primers (M13F and M13R) are used (Paster et al., 2001). 
The first step in DNA sequence analysis is to clean each raw DNA sequence file of poor-quality nucleotide bases. The nucleotide quality is obtained from the chromatograms generated during sequencing. The chromatogram is a representation of the DNA sequence. It presents the relative signal strength of each DNA base (adenine, cytosine, thiamine, and guanine), which determines the position of nucleotides within the sequence (CodonCode Corporation, 2009). There are multiple programs to aid in the cleaning process of DNA sequences. CodonCode Aligner (CodonCode Corporation, Dedham, Massachusetts) is a program that will automatically remove portions of the DNA sequence with weak or mixed signals. CodonCode Aligner can also remove vector sequence, improving the overall quality of the insert.

Once sequences are cleaned they must be compared to a database to confirm their TM7 identity. The National Center for Biotechnology Information (NCBI) contains the GenBank database that houses non-redundant DNA sequences (Altschul et al., 1997) which includes thousands of 16S rRNA genes. NCBI Basic Local Alignment Search Tool (BLAST) can be utilized to compare users' sequences to those housed in GenBank. The BLAST tool allows users to determine the similarity or novelty of their sequences (Altschul et al., 1997).

In order to conduct a phylogenetic analysis, the DNA sequences must be aligned and compared. The Greengenes database only houses $16 \mathrm{~S}$ rRNA gene sequences and provides multiple tools for sequence preparation (DeSantis et al., 2006). The Near Alignment Space Termination (NAST) tool is one such program that aligns 16S rDNA sequences to a 7,682-character scaffold, allowing for a systematic approach for $16 \mathrm{~S}$ 
rDNA comparisons (DeSantis Jr et al., 2006). This scaffold was created using 10,000 representative 16S rRNA genes from the Greengenes database. Furthermore, the Greengene database provides chimera checking utilizing Bellerophon. A chimera is an artifact of PCR, which contains multiple sequencing fragments from different organisms in a single sequence (Cole et al., 2003). Bellerophon screens the user-imported sequences for the presence of chimeras (Cole et al., 2003). Chimeric sequences are subsequently discarded from the analysis.

Phylogenetic relationships of 16S rRNA genes are performed by software such as ARB. ARB is an open source software that allows the comparison of 16S rRNA (Ludwig et al., 2004). ARB compares both the primary and secondary structure of 16S rRNA gene sequences to 236,469 reference sequences making it the most powerful software to conduct rRNA comparisons. Phylogenetic trees can be constructed within the ARB software by using a neighbor-joining algorithm. In this algorithm, each organism is placed in an individual branch (Ludwig et al., 2004). A 'node' signifies the location where the branches separate. Because Neighbor-joining trees assume a molecular clock, each node signifies a common ancestor (Ludwig et al., 2004). The branch lengths depict the organism divergence to its common ancestor, based on nucleotide mutations. The longer the branch, the more divergent the two organisms are from one another (Ludwig et al., 2004). Furthermore, the probability that each node occurred is signified by a bootstrap value (Ludwig et al., 2004). Repeating the generation of the tree at least 100 times derives a bootstrap value, which is the percentage that the node occurred at a particular location (Ludwig et al., 2004). Finally, to increase the bootstrap values, thus 
the accuracy of the tree, a distantly related sequence is added to root the tree (Ludwig et al., 2004). This root allows all sequences to be compared to a single common ancestor. 


\section{Quantitative PCR}

Quantitative polymerase chain reaction (qPCR) utilizes fluorescently labeled probes or dyes in order to determine the absolute quantity of a target nucleic acid sequence (Applied Biosystems, 2005). Quantification of nucleic acid targets in real time is possible in qPCR by fluorescence readings that are taken at the end of every PCR cycle. There are two main methods in which fluorescence can be detected by the qPCR thermalcycler; the first utilizes nucleic acid dyes, and the second uses fluorescently labeled probes (Applied Biosystems, 2005).

In the first method, a fluorescently labeled dye such as SYBR green is responsible for the fluorescence of target nucleic acids. SYBR green is a general nucleic acid stain that binds to double-stranded DNA (dsDNA) but not single-stranded DNA (ssDNA) (Applied Biosystems, 2005). Due to this feature, SYBR green will bind only to newly synthesized dsDNA amplicons at the end of each PCR cycle but will not bind and fluoresce ssDNA such as primers or probes. According to Applied Biosystems, this method is preferred for determining the abundance of a sample with a known DNA composition such as a purified plasmid; however, it is not suitable for samples that contain a variety of unknown sequences, such as those obtained from genomic DNA extractions from environmental or human-associated mixed microbial communities. This is because SYBR green is a non-specific dye, binding to any double-stranded nucleic acid, including non-specific PCR products, thus overestimating the targets' true abundance.

In the second and more precise method, a TaqMan Probe assay is utilized. A TaqMan probe is an oligonucleotide probe that is complementary to the target DNA 
strand and is used for inducing fluorescence to the target amplicon (Applied Biosystems, 2005). The TaqMan probe is tethered to a fluorescent reporter on its 5 ' end and a quencher on the 3' end. When excited by a light source of correct wavelength, the fluorescent reporter emits energy in the form of light (fluorescence) that can be detected by the qPCR machine (Applied Biosystems, 2005). However, the Applied Biosystems manual states that while the quencher remains attached to the probe, the quencher absorbs the emitted light from the reporter, fluorescence is not produced, preventing the detection of the probe. In order for the reporter to be detected, it must be cleaved from the probe. In addition to the fluorescent probe, TaqMan uses two primers that, like PCR, flank the piece of DNA to be amplified. The TaqMan probe is designed to bind to a DNA target sequence between the two primers. During qPCR, all intact probes do not fluoresce due to the presence of the quencher, however, as Taq Polymerase elongates a target amplicon, the polymerase will reach the probe bound to DNA and will cleave the reporter from the attached probe, the fluorescence from the reporter is no longer quenched, allowing for its detection (Applied Biosystems, 2005). As the qPCR cycles progress, more probes are cleaved and more fluorescence signal is produced. Hence, qPCR is a quantitative method because the amount of fluorescence detected is linked to the amount of a particular target DNA in a sample. As with FISH probes, TaqMan probes can be designed to target a variety of sample sizes. Broad range probes such as BAC 338 have been designed to target most prokaryotes (Murray et al., 1998), and specific probes such as TM7a 1033 have been designed to target a specific clade of TM7, TM7a (Dinis et al., 2011). In order to prevent possible fluctuations between $\mathrm{qPCR}$ reactions caused by pipetting or 
concentration errors, the ABI mastermix provides a passive reference dye. The passive reference dye is utilized to normalize reporter detection fluctuations between qPCR reactions (Applied Biosystems, 2005).

Utilizing qPCR to detect the abundance of TM7 has been performed previously (Brinig et al., 2003; Dinis et al., 2011). Brinig et al. (2003), developed a protocol for the quantification of total bacteria and TM7 specific populations in Human subgingival crevice samples. In this study, broad range $16 \mathrm{~S}$ primers, BAC 8F and BAC 515R (Lane et al., 1985), were used in conjunction with TaqMan probe BAC 338 (Murray et al., 1998) for total bacterial quantification. TM7 quantities were determined by utilizing TM7 specific primers, TM7 910F and TM7 1177R in conjunction with TaqMan probe TM7 1093 (Brinig et al., 2003). Thermocycling conditions in this study were preformed according to Applied Biosystems protocols with a modification to the annealing temperatures. The total bacteria quantification reaction utilized three separate annealing temperatures: $55^{\circ} \mathrm{C}, 60^{\circ} \mathrm{C}$, and $65^{\circ} \mathrm{C}$ (Brinig et al., 2003). The TM7 quantification reactions used a single annealing temperature of $61^{\circ} \mathrm{C}$ (Brinig et al., 2003). In order to define the quantification of bacteria within the samples, a standard curve was generated utilizing a plasmid with a known copy number and was serially diluted. The plasmid utilized for the generation of the standard curve encompassed a TM7 sequence that contained complimentary targets to all primers and probes utilized in the study (Brinig et al., 2003).

Once rRNA gene copy numbers are obtained by the qPCR reaction, they must be converted to cells per gram. Factored in that conversion is the fact that some prokaryotic 
genomes contain more than one copy of the same 16S rRNA gene, some containing up to 15 16S rRNA gene copies per cell (Acinas et al., 2004). Based on analyses of complete bacterial genomes, it was determined that the average bacterium contains $3.516 \mathrm{~S}$ rRNA genes per cell (Acinas et al., 2004). Based on the two published TM7 genomes, TM7 appear to have two 16S rRNA gene copies per cell (Marcy et al., 2007; Podar et al., 2007). Therefore, a 3.5 16S rRNA gene copy number per cell was used when quantifying bacteria, and two copy numbers was be used when quantifying TM7. 


\section{Materials and Methods}

\section{Patient Selection}

Six healthy individuals were selected randomly to participate in this study. The patients were chosen based on their availability to be sampled by the dentist. In compliance with the Institutional Review Board (IRB) \#F0904009, each patient was asked to sign a consent form and then asked to fill out an overall health survey (Table 2). Once the surveys were collected, each individual was given a randomly generated ID number to protect patient identity.

\section{Sample Collection and Processing}

A local licensed dentist first determined the health condition of each patient's tooth based on quantitative (measurements of pocket depths, Figure 1) and qualitative (general observations of oral tissue health) observations. Then, the same dentist used sterile techniques to collect all oral plaque samples with dental picks (Figure 1). Five to six individual teeth were sampled from each patient. The subgingival plaque sample from each tooth was notarized based on the tooth's position, anatomical location, and sampling surface (facial or lingual) (Figure 2). Each individual tooth's collected oral plaque was put into individual $1.5 \mathrm{~mL}$ sterile eppendorf tubes (Eppendorf, Hauppauge, NY). Each tube contained $200 \mu$ sterile 1x PBS solution, was pre-weighed in a Mettler Toledo AB54-S balance (Mettler Toledo, Columbus, $\mathrm{OH}$ ), and labeled with the patients ID followed by the tube number $(1-6)$. Hence, each tube had a unique number linked 
to the patient and the exact tooth from which the plaque was collected.

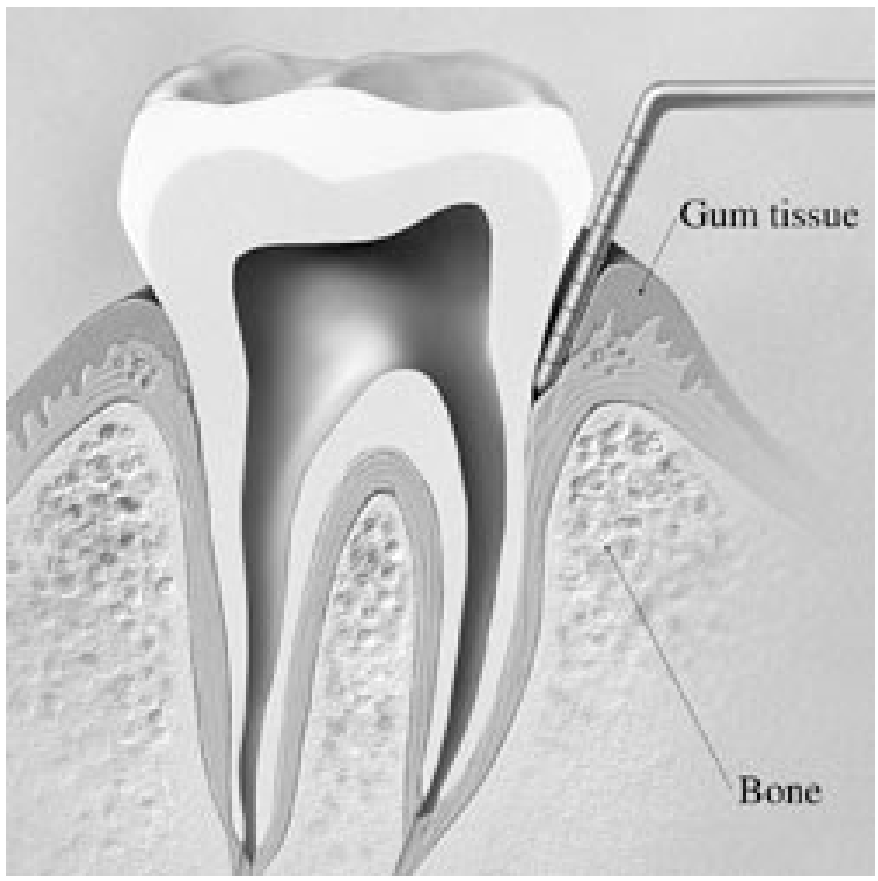

Figure 1. Use of probe to measure periodontal pocket depth (nidcr.nig.gov, 2013). The depth of each periodontal pocket was measured as shown to determine the health status of each tooth. 


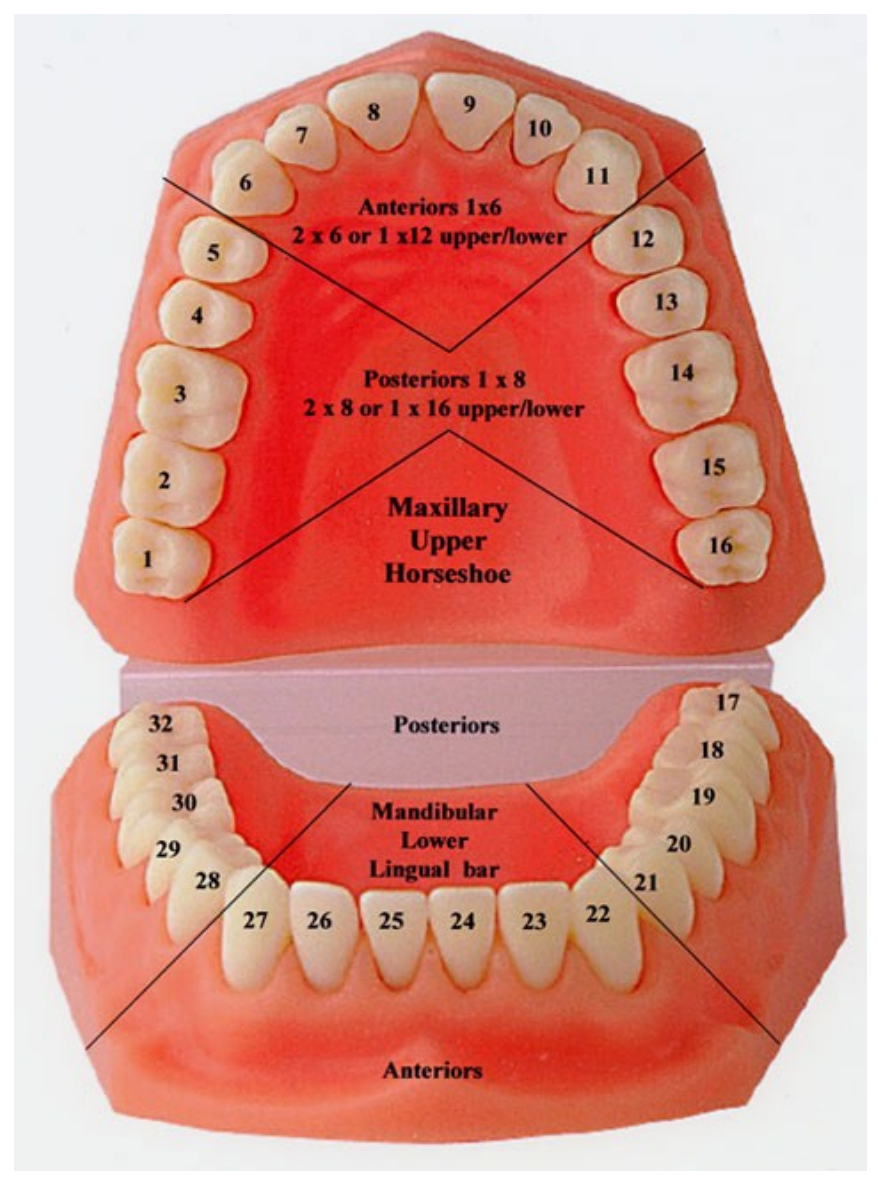

Figure 2. Universal tooth numbering chart (DentalImplants-USA, 2013). Each number represents a unique tooth. Teeth are categorized based on their anatomical position, posterior (\#1-5, 12 - 21, 28 - 32) or anterior (\#6 - 11, $22-27)$, and sampling surface, facial (side of tooth facing the cheek) or lingual (side of tooth facing the tongue). 
Samples were transferred to the laboratory on ice, and processed within $1 \mathrm{~h}$ of sampling. Each tube was weighed again in a Mettler Toledo AB54-S balance (Mettler Toledo, Columbus, $\mathrm{OH}$ ) to determine the net weight of collected oral plaque per sample. After each sample's weight was determined, DNA was immediately extracted.

\section{DNA Extraction}

Bacterial genomic DNA was extracted from each sample using a Qiagen DNeasy Blood and Tissue Kit (Qiagen, Valencia, California). DNA was extracted according to the manufacturer's gram-positive bacteria protocol (protocol revision 07/2006). Following DNA extraction, concentration and purity of DNA was determined using a Nanodrop ND-1000 spectrophotometer (Thermo Scientific, Waltham, MA) with version 3.7 software (Thermo Scientific, Waltham, MA). All extracted nucleic acid was stored at $-20^{\circ} \mathrm{C}$.

\section{Bacteria 16S rRNA Gene Amplification}

To determine if the bacterial genomic DNA was successfully extracted, PCR was run to screen each sample for the presence of the 16S rRNA gene. Broad-range primers BAC $8 \mathrm{~F}$ and $515 \mathrm{R}$ were used to amplify the $16 \mathrm{~S}$ rRNA target (Table 1). PCR amplification was performed using a 1/10 dilution of each extracted sample. Each individual $25 \mu 1$ PCR reaction contained the following reagents: $2.5 \times 10^{-2}$ units of GOTaq Flexi DNA polymerase (Promega, Madison, Wisconsin), 1x GOTaq Reaction Buffer (Promega, Madison, Wisconsin), $2.0 \mathrm{mM} \mathrm{MgCl} 2,0.2 \mathrm{mM}$ of each deoxyribonucleotide, $0.2 \mu \mathrm{M}$ of each forward and reverse primer, and 5 to $50 \mathrm{ng}$ of nucleic acid. The PCR 
reactions were carried out using an Applied Biosystemes 2720 Thermal Cycler (Applied Biosystems, Foster City, California) with the following cycling conditions: initial denaturation step of $95^{\circ} \mathrm{C}$ for $2 \mathrm{~min}$ then 35 cycles of $95^{\circ} \mathrm{C}$ for $30 \mathrm{sec}, 55^{\circ} \mathrm{C}$ for $30 \mathrm{sec}$, and $72^{\circ} \mathrm{C}$ for $1.5 \mathrm{~min}$, followed by a final elongation step of $72^{\circ} \mathrm{C}$ for $5 \mathrm{~min}$. 
Table 1. Primers and Probes

\begin{tabular}{|c|l|l|l|}
\hline \multirow{4}{*}{$\begin{array}{c}\text { General } \\
\text { Bacteria }\end{array}$} & BAC 8F & PCR Primer & AGA GTT TGA TCM TGG CTC AG \\
\cline { 2 - 4 } & BAC 515R & PCR Primer & KAC CGC GGC KGC TGG CA \\
\cline { 2 - 4 } & BAC 338I & qPCR Probe & GCT GCC TCC CGT AGG AGT \\
\cline { 2 - 4 } & BAC 338II & qPCR Probe & GCA GCC ACC CGT AGG TGT \\
\cline { 2 - 4 } & TM7 910F & qPCR Probe & GCT GCC ACC CGT AGG TGT \\
\hline \multirow{3}{*}{$\begin{array}{c}\text { General } \\
\text { TM7 }\end{array}$} & TM7 1177R & PCR Primer & CAT AAA GGA ATT GAC GGG GAC \\
\cline { 2 - 4 } & TM7 1093 & qPCR Probe & AGT CCA TCA ACG AGC GCA ACC \\
\cline { 2 - 4 } TM7a & TM7a 997F & PCR Primer & TCC CGA GAA GAT TTA CG \\
\hline Specific & TM7 1177R & PCR Primer & GAC CTG ACA TCA TCC CCT CCT TCC \\
\cline { 2 - 4 } & TM7a 1033 & qPCR Probe & ATC TGT CAC CGA GTT CCA \\
\hline
\end{tabular}

Following PCR amplification, amplicons were run on a 1.5\% agarose gel (International Biotechnologies Inc., New Haven, Connecticut) containing 0.025\% Ethidium Bromide. Gels were casted on a Horizon 58 gel electrophoresis system (Invitrogen, Carlsbad, California) with a FB300 electrophoresis power supply (Fisher Scientific, Waltham, Massachusetts), running at $90 \mathrm{~V}$ and $400 \mathrm{~mA}$ for $30 \mathrm{~min}$. Following electrophoresis, gel visualization and imaging was performed on a Bio-Rad Universal Hood II system (Bio-Rad, Hercules, California), and annotated using Quantity One Version 4.6 Software (Bio-Rad, Hercules, California). 


\section{Quantitative PCR}

Quantitative PCR (qPCR) was performed on all samples that tested positive for the presence of $16 \mathrm{~S}$ rDNA using PCR as described above. A TaqMan probe-based absolute quantification assay was performed on an Applied Biosystems 7300 Real Time PCR System (Applied Biosystems, Foster City, California). For each oral sample, three subgroups of prokaryotes were quantified using qPCR: total bacteria, total TM7, and total TM7a. Each experiment was run three times to generate an average, and each oral sample was run in triplicate per experiment, for a total of nine data points per oral sample. As part of the absolute quantification assay a standard curve was generated for each run to determine the amount of $16 \mathrm{~S}$ rDNA in the samples.

In order to generate a standard curve, a positive control plasmid was utilized that contained complimentary targets for all qPCR primers and probes used in this study. The concentration of the positive control plasmid was determined using a Nanodrop ND-1000 spectrophotometer (Thermo Scientific, Waltham, MA) and diluted to a final concentration of $5.6 \mathrm{ng} / \mathrm{ul}$, which correlates to be $1 \times 10^{9}$ molecules of plasmid per ul. For the generation of each standard curve the positive control plasmid was serially diluted from $1 \times 10^{8}$ to 1 plasmid copy number(s) per ul, hence each standard curve had eight data points. As with oral samples, each plasmid dilution was run in triplicate for each of the three experimental runs.

Experimental setup including annotating the standard curve controls and oral samples was performed with the 7300 System SDS software version 1.4 (Applied 
Biosystems, Foster City, California) using the absolute quantification platform.

Experimental parameters and cycling conditions were as follows for each of the three phylogenetic groups targeted:

Bacterial quantification. Each qPCR reaction contained a final volume of $20 \mu \mathrm{l}$ composed of $10 \mu 1$ TaqMan Universal PCR Master Mix, No AmpErase UNG (Applied Biosystems, Foster City, California), $1.8 \mu \mathrm{M}$ of the forward primer BAC $8 \mathrm{~F}, 3.6 \mu \mathrm{M}$ of the reverse primer BAC 515R, and contained $0.1 \mu \mathrm{M}$ of each of the following TaqMan probes: BAC 338I, BAC 338II, and BAC 338III (Table 1). The TaqMan probes contained a FAM fluorescent reporter and a black hole quencher. Cycling parameters were defined as follows: initial denaturation and Taq activation step of $95^{\circ} \mathrm{C}$ for $10 \mathrm{~min}$, then 45 cycles of $95^{\circ} \mathrm{C}$ for $30 \mathrm{sec}, 55^{\circ} \mathrm{C}$ for $30 \mathrm{sec}, 60^{\circ} \mathrm{C}$ for $45 \mathrm{sec}, 65^{\circ} \mathrm{C}$ for $15 \mathrm{sec}$, and $72^{\circ} \mathrm{C}$ for $30 \mathrm{sec}$ as previously published (Brinig et al. 2003). At the end of each $72^{\circ} \mathrm{C}$ elongation step, fluorescent levels were read and recorded automatically by the qPCR machine.

TM7 quantification. Each qPCR reaction contained a final volume of $20 \mu 1$ composed of $10 \mu 1$ TaqMan Universal PCR Master Mix, No AmpErase UNG (Applied Biosystems, Foster City, California), $0.9 \mu \mathrm{M}$ of the forward primer TM7 910F, $0.9 \mu \mathrm{M}$ of the reverse primer TM7 1177R, and $0.1 \mu \mathrm{M}$ of TaqMan probe TM7 1093 containing a FAM fluorescent reporter and black hole quencher (Table 1). Cycling parameters were defined as follows: initial denaturation and Taq activation step of $95^{\circ} \mathrm{C}$ for $10 \mathrm{~min}$, then 
45 cycles of $95^{\circ} \mathrm{C}$ for $30 \mathrm{sec}, 61^{\circ} \mathrm{C}$ for $30 \mathrm{sec}$, and $72^{\circ} \mathrm{C}$ for $30 \mathrm{sec}$. At the end of each $72^{\circ} \mathrm{C}$ elongation step, fluorescent levels were read and recorded.

TM7a quantification. Each qPCR reaction had a final volume of $20 \mu$ composed of 10 $\mu 1$ TaqMan Universal PCR Master Mix, No AmpErase UNG (Applied Biosystems, Foster City, California), $0.9 \mu \mathrm{M}$ of the forward primer TM7a 997F, $0.9 \mu \mathrm{M}$ of the reverse primer TM7 1177R, and $0.1 \mu \mathrm{M}$ of TaqMan probe TM7a 1033 containing a FAM fluorescent reporter and black hole quencher (Table 1). Cycling parameters were defined as follows: initial denaturation and Taq activation step of $95^{\circ} \mathrm{C}$ for $10 \mathrm{~min}$, then 45 cycles of $95^{\circ} \mathrm{C}$ for $30 \mathrm{sec}, 61^{\circ} \mathrm{C}$ for $30 \mathrm{sec}$, and $72^{\circ} \mathrm{C}$ for $30 \mathrm{sec}$. At the end of each $72^{\circ} \mathrm{C}$ elongation step, fluorescent levels were read and recorded.

\section{qPCR Raw Data Conversions}

Following each run, the quantification of targeted 16S rRNA genes was obtained, commonly referred to as gene copy number. Because each sample starting material (plaque) was of different weight, measurements were normalized by the original plaque weight in order to compare the quantification of 16S rRNA gene copy number among the various samples. In addition the number of $16 \mathrm{~S}$ rRNA genes in a bacterial genome varies depending on the phylogenetic group. Therefore, an equation was used to convert total 16S rRNA genes to cells/g of pelleted oral plaque (Figure 3). The following conversion was performed to obtain cells/g of pelleted oral plaque from the raw qPCR data: 1) Corrections for gene copy number per cell, using an estimated 3.5 average rRNA gene copy number per cell for total bacteria quantification (Klappenbach et al., 2001) and 2.0 
average rRNA gene copy number per cell for total TM7 and TM7a (Marcy et al., 2007;

Podar et al., 2007), 2) corrections for DNA sample dilution used for qPCR reactions, and 3) corrections for DNA concentration due to DNA extraction methods.

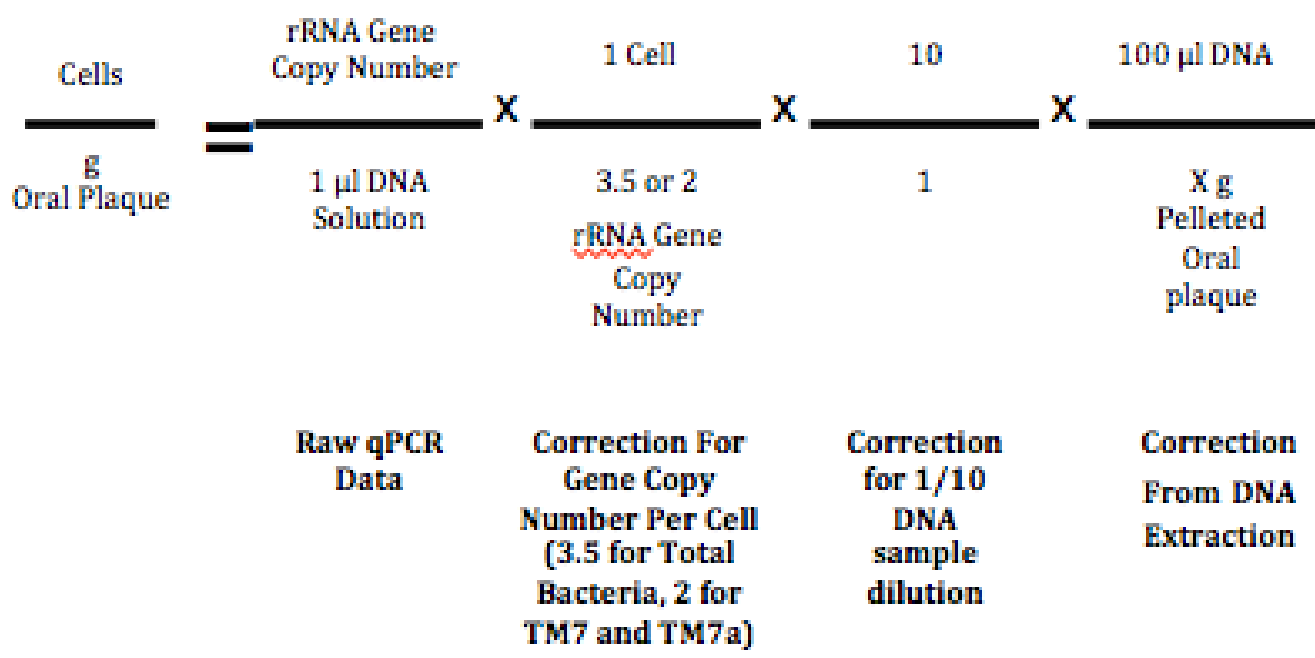

Figure 3. Calculation for converting raw qPCR data, rRNA gene copy number $/ \mu 1$, to cells/g of pelleted oral plaque. Conversions included corrections for gene copy number per cell, sample dilution used, and changes in volume during DNA extraction. 


\section{Results}

\section{Patient Selection}

Four males and two females participated in this study (Table 2). The average patient was in their mid twenties. Two patients were current or previous smokers. All patients brushed their teeth twice daily; however, the frequency of dental flossing ranged from 1 7 times per week. Two patients experienced bleeding upon flossing. Three patients bit their fingernails, and no patients had extensive crown or bridge work. 
Table 2. Summary of patient health surveys. All reports were collected the day of plaque collection

\begin{tabular}{|c|c|c|c|c|c|c|}
\hline & \multicolumn{6}{|c|}{ Patient ID } \\
\hline & DXD & ETP & FYZ & GMO & KPM & JNW \\
\hline Gender & $\mathrm{F}$ & $\mathrm{M}$ & $\mathrm{M}$ & $\mathrm{M}$ & $\mathrm{M}$ & $\bar{F}$ \\
\hline Age & $26-30$ & $31+$ & $21-25$ & $21-25$ & $26-30$ & $21-25$ \\
\hline Height & $53^{\prime}$ & $5^{\prime} 10^{\prime \prime}$ & $6^{\prime} 0^{\prime \prime}$ & $5^{\prime} 10^{\prime \prime}$ & $6^{\prime} 0^{\prime \prime}$ & $5^{\prime} 4^{\prime \prime}$ \\
\hline Weight & - & 178 & 170 & 130 & 165 & 104 \\
\hline $\begin{array}{l}\text { Health } \\
\text { condition }\end{array}$ & No & No & No & No & No & No \\
\hline Smoker & Yes & No & No & No & Yes & No \\
\hline Allergies & Yes & No & No & No & Yes & No \\
\hline $\begin{array}{c}\text { Brush } \\
\text { Frequency }\end{array}$ & $2 \mathrm{x}$ & $2 \mathrm{x}$ & $2 \mathrm{x}$ & $2 x$ & $2 \mathrm{x}$ & $2 \mathrm{x}$ \\
\hline Floss & $7 x$ & $6 x$ & $5 x$ & $1 \mathrm{x}$ & $7 x$ & $5 x$ \\
\hline Bleeding Gums & Yes & No & Yes & No & No & Yes \\
\hline Finger Biting & No & No & Yes & No & Yes & Yes \\
\hline $\begin{array}{c}\text { Extensive } \\
\text { Crown or } \\
\text { Bridge Work }\end{array}$ & No & No & No & No & No & No \\
\hline
\end{tabular}




\section{Sample Collection and Processing}

Between five and six oral plaque samples were collected from each of the six patients for a total of 34 samples (Table 3). An average of $0.0028 \mathrm{~g}$ of dental plaque was collected from each sample with a range from $0.0013 \mathrm{~g}$ to $0.0048 \mathrm{~g}$ (Table 3). Among the 34 samples, 23 were from males and 11 from females. The sites from which samples were collected included 19 from the facial side and 15 from lingual, whereas 23 samples were from posterior sites and 11 from anterior sites (Table 3). Pocket depth (PD) was used as a preliminary measure of the gingival health status. $\mathrm{PD} \leq 3 \mathrm{~mm}$ are considered healthy, whereas PD $\geq 4$ are considered unhealthy (or diseased). The average PD among all sampled sites was $2.7 \mathrm{~mm}$ with a range from $2 \mathrm{~mm}$ to $5 \mathrm{~mm}$. Thirty sites were classified as healthy ( $\mathrm{PD} \leq 3 \mathrm{~mm}$ ) and four sites exhibited gingivitis ( $\mathrm{PD} \geq 4$ ) (Table 3 ). 
Table 3. Subgingival Plaque Weights. Each tube used to collect the samples was labeled and filled with $200 \mu 1$ sterile $\mathrm{H}_{2} \mathrm{O}$ and weighed to obtain the initial tubes weight. Following sample collection, each tube was weighed a second time to determine the weight of the subgingival plaque. Pocket depth was determined by the dentist prior to collecting the sample.

\begin{tabular}{|c|c|c|c|c|c|c|c|c|c|c|c|c|}
\multicolumn{1}{c|}{} & \multicolumn{9}{c|}{ DXD } & \multicolumn{10}{c|}{ ETP } \\
\hline Sample & 1 & 2 & 3 & 4 & 5 & 6 & 1 & 2 & 3 & 4 & 5 & 6 \\
\hline Tooth & $2 \mathrm{~F}$ & $6 \mathrm{~F}$ & $13 \mathrm{~L}$ & $19 \mathrm{~L}$ & $24 \mathrm{~F}$ & $31 \mathrm{~F}$ & $2 \mathrm{~F}$ & $5 \mathrm{~F}$ & $8 \mathrm{~L}$ & $30 \mathrm{~L}$ & $27 \mathrm{~F}$ & $13 \mathrm{~F}$ \\
\hline $\begin{array}{c}\text { Tube } \\
\text { (g) }\end{array}$ & 1.0070 & 1.0033 & 1.0129 & 1.0040 & 1.0021 & 1.0052 & 1.0036 & 1.0079 & 1.0071 & 1.0077 & 1.0035 & 1.0044 \\
\hline $\begin{array}{c}\text { Tube } \\
\text { w/sample } \\
\text { (g) }\end{array}$ & 1.0091 & 1.0068 & 1.0158 & 1.0061 & 1.0043 & 1.0075 & 1.0057 & 1.0099 & 1.0094 & 1.0099 & 1.0058 & 1.0077 \\
\hline $\begin{array}{c}\text { Sample } \\
\text { (g) }\end{array}$ & 0.0021 & 0.0035 & 0.0029 & 0.0021 & 0.0022 & 0.0023 & 0.0021 & 0.0020 & 0.0023 & 0.0022 & 0.0023 & 0.0033 \\
\hline $\begin{array}{c}\text { Pocket } \\
\text { Depth } \\
\text { (mm) }\end{array}$ & 3 & 3 & 3 & 2 & 3 & 2 & 2 & 5 & 3 & 3 & 2 \\
\hline
\end{tabular}


Table 3. Subgingival Plaque Weights, continued.

\begin{tabular}{|c|c|c|c|c|c|c|c|c|c|c|c|c|}
\multicolumn{1}{c|}{} & \multicolumn{9}{c|}{ FYZ } & \multicolumn{10}{c|}{ GMO } \\
\hline Sample & 1 & 2 & 3 & 4 & 5 & 6 & 1 & 2 & 3 & 4 & 5 & 6 \\
\hline Tooth & $2 \mathrm{~F}$ & $7 \mathrm{~L}$ & $13 \mathrm{~F}$ & $31 \mathrm{~F}$ & $25 \mathrm{~F}$ & $20 \mathrm{~L}$ & $2 \mathrm{~F}$ & $8 \mathrm{~F}$ & $15 \mathrm{~L}$ & $20 \mathrm{~L}$ & $26 \mathrm{~F}$ & $31 \mathrm{~F}$ \\
\hline Tube (g) & 1.0129 & 0.9895 & 1.0026 & 1.0075 & 1.0051 & 1.0004 & 1.0126 & 1.0212 & 1.0064 & 1.0082 & 1.0039 & 1.0043 \\
\hline $\begin{array}{c}\text { Tube } \\
\text { w/sample } \\
\text { (g) }\end{array}$ & 1.0161 & 0.9918 & 1.0052 & 1.0107 & 1.0084 & 1.0034 & 1.0153 & 1.0244 & 1.0107 & 1.0107 & 1.0087 & 1.0076 \\
\hline $\begin{array}{c}\text { Sample } \\
\text { (g) }\end{array}$ & 0.0032 & 0.0023 & 0.0026 & 0.0032 & 0.0033 & 0.0030 & 0.0027 & 0.0032 & 0.0043 & 0.0025 & 0.0048 & 0.0033 \\
\hline $\begin{array}{c}\text { Pocket } \\
\text { Depth } \\
\text { (mm) }\end{array}$ & 3 & 2 & 4 & 4 & 2 & 4 & 2 & 3 & 2 & 3 & 3 & 2 \\
\hline
\end{tabular}


Table 3. Subgingival Plaque Weights continued.

\begin{tabular}{|c|c|c|c|c|c|c|c|c|c|c|}
\hline & \multicolumn{10}{|c|}{ Patient } \\
\hline & \multicolumn{5}{|c|}{ JNW } & \multicolumn{5}{|c|}{ KPM } \\
\hline Sample & 1 & 2 & 3 & 4 & 5 & 1 & 2 & 3 & 4 & 5 \\
\hline Tooth & $4 \mathrm{~L}$ & $10 \mathrm{~L}$ & $20 \mathrm{~L}$ & $24 \mathrm{~F}$ & $30 \mathrm{~L}$ & $2 \mathrm{~F}$ & $20 \mathrm{~L}$ & $18 \mathrm{~L}$ & $31 \mathrm{~L}$ & $11 \mathrm{~F}$ \\
\hline $\begin{array}{c}\text { Tube } \\
\text { (g) }\end{array}$ & 1.0006 & 0.9890 & 1.0057 & 1.0039 & 1.0033 & 1.0062 & 1.0046 & 1.0044 & 1.0038 & 1.0122 \\
\hline $\begin{array}{c}\text { Tube } \\
\text { w/sample } \\
\text { (g) }\end{array}$ & 1.0043 & 0.9918 & 1.0081 & 1.0071 & 1.0069 & 1.0095 & 1.0081 & 1.0066 & 1.0051 & 1.0136 \\
\hline $\begin{array}{c}\text { Sample } \\
\text { (g) }\end{array}$ & 0.0037 & 0.0028 & 0.0024 & 0.0032 & 0.0036 & 0.0033 & 0.0035 & 0.0022 & 0.0013 & 0.0014 \\
\hline $\begin{array}{c}\text { Pocket } \\
\text { Depth } \\
\text { (mm) }\end{array}$ & 3 & 2 & 3 & 3 & 3 & 3 & 2 & 3 & 2 & 2 \\
\hline
\end{tabular}




\section{DNA Extraction}

Genomic DNA extracted yielded an average of $14.27 \mathrm{ng} / \mu \mathrm{l}$ with a range of 1.62 $\mathrm{ng} / \mu \mathrm{l}-51.34 \mathrm{ng} / \mu \mathrm{l}$ (Table 4). DNA purity was determined by the A260/A280 ratio, which averaged $1.90 \pm 0.30$, indicating that the extracted DNA contained predominantly DNA (Table 4). 
Table 4. Genomic DNA Extraction. Extractions were performed using the Qiagen DNeasy Blood and Tissue Kit. DNA concentration expressed in $n g / \mu l$ using a NanoDrop spectrophotometer. DNA purity is expressed as the A260/A280 ratio.

Tooth \# followed the standard numbering of teeth used in dentistry. $\mathrm{F}=$ facial and $\mathrm{L}=$ lingual side of the tooth.

\begin{tabular}{|c|c|c|c|c|c|c|c|c|c|c|c|c|c|c|c|c|c|}
\hline \multirow[b]{3}{*}{ Sample } & \multicolumn{17}{|c|}{ Patient } \\
\hline & \multicolumn{6}{|c|}{ DXD } & \multicolumn{6}{|c|}{ ETP } & \multicolumn{5}{|c|}{ JNW } \\
\hline & 1 & 2 & 3 & 4 & 5 & 6 & 1 & 2 & 3 & 4 & 5 & 6 & 1 & 2 & 3 & 4 & 5 \\
\hline Tooth & $2 \mathrm{~F}$ & $6 \mathrm{~F}$ & $13 \mathrm{~L}$ & $19 \mathrm{~L}$ & $24 \mathrm{~F}$ & $31 \mathrm{~F}$ & $2 \mathrm{~F}$ & $5 \mathrm{~F}$ & $8 \mathrm{~L}$ & $30 \mathrm{~L}$ & $27 \mathrm{~F}$ & $13 \mathrm{~F}$ & $4 \mathrm{~L}$ & $10 \mathrm{~L}$ & $20 \mathrm{~L}$ & $24 \mathrm{~F}$ & $30 \mathrm{~L}$ \\
\hline $\mathrm{ng} / \mu \mathrm{l}$ & 24.94 & 19.46 & 12.22 & 26.86 & 9.67 & 18.63 & 1.62 & 6.05 & 9.65 & 9.03 & 3.07 & 12.63 & 6.69 & 7.26 & 13.65 & 4.46 & 13.54 \\
\hline $\begin{array}{c}\text { A260/A280 } \\
\text { Ratio }\end{array}$ & 1.93 & 1.95 & 1.92 & 1.92 & 1.81 & 2.03 & 1.71 & 1.69 & 2.57 & 1.81 & 2.14 & 1.86 & 2.14 & 1.5 & 1.5 & 2.16 & 1.82 \\
\hline
\end{tabular}

Table 4. Genomic DNA Extraction Continued.

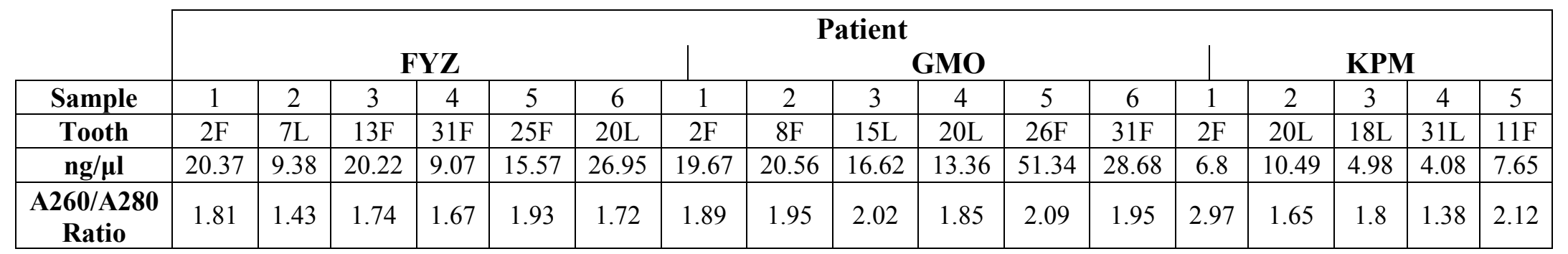




\section{Bacteria 16S rRNA Gene Amplification}

Initial PCR screening showed that all 34 oral samples contained the $16 \mathrm{~S}$ rRNA gene from bacteria as determined from amplifying samples with general bacteria $16 \mathrm{~S}$ rRNA primers, BAC 8F and BAC 515R. All samples were compared to a positive control plasmid in a 1.5\% agarose gel. A 1/10 dilution of all DNA samples was used to conserve DNA (Figure 4).
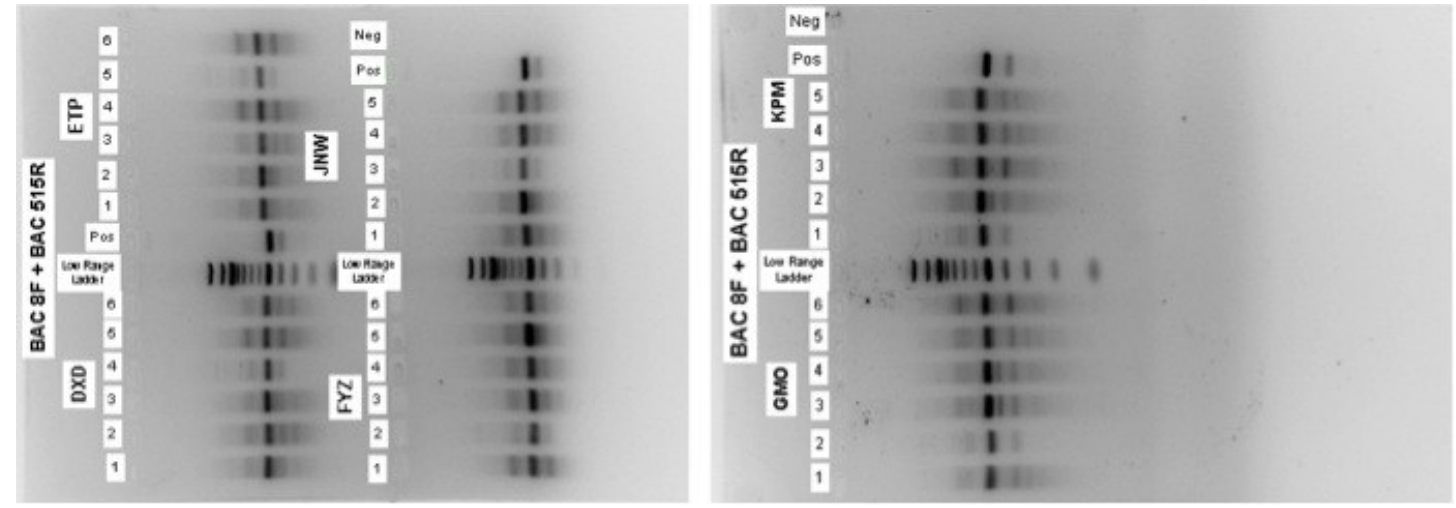

Figure 4. PCR screening results from extracted genomic DNA using BAC 8F and BAC 515R. A 1/10 dilution of each genomic DNA sample was used. PCR products were run on a $1.5 \%$ agarose gel with a low range ladder and positive control plasmid as a reference. 


\section{Quantitative PCR}

Real time quantitative PCR was used to quantify the 16S rRNA gene in each oral plaque sample. Three separate qPCR assays were performed to quantify the i) total bacteria, ii) TM7, and iii) TM7a populations. qPCR quantification was based on a standard curve generated using a positive control plasmid serially diluted from $10^{8}$ to 1 gene copy number per $\mu 1$. At the end of each run, the ABI $7300 \mathrm{qPCR}$ software produced a best-fit line using five sequential dilution points of the standard curve (Table 5). From the slope of the best-fit line the coefficient of correlation $\left(\mathrm{R}^{2}\right)$ was calculated. The ideal qPCR run (100\% efficiency) has a slope of -3.33 and an $\mathrm{R}^{2}$ of $100 \%$, indicating each $16 \mathrm{~S}$ rDNA gene in the sample was copied (doubled) every qPCR cycle. For all three qPCR target groups in the oral samples (Bacteria TM7 and TM7a) the $\mathrm{R}^{2}$ values were greater than $99 \%$ (Table 5), signifying high accuracy of results. The normalized data collected over three runs produced amplification efficiencies near the ideal value of one (Table 5). Among the six patients, all were positive for the presence of bacteria as expected. TM7 was detected in all patients and in 32 of 34 (94.1\%) samples. TM7a was detected in 5 of $6(83 \%)$ patients and in 22 of $34(64.7 \%)$ samples. 
Table 5. Amplification efficiency values from qPCR experiments. Each assay consisted of three runs in triplicates per sample, total sample population $(n=9)$. Numbers in parenthesis are \pm standard error of the mean.

\begin{tabular}{|c|c|c|c|c|}
\hline $\begin{array}{c}\text { qPCR Assay } \\
\text { Target }\end{array}$ & $\begin{array}{c}\text { Amplification } \\
\text { Efficiency }\end{array}$ & Slope & $\mathbf{R}^{2}$ & $\begin{array}{c}\text { Standard } \\
\text { Range }\end{array}$ \\
\hline Bacteria & $0.96(0.013)$ & $3.42(0.035)$ & $>99 \%$ & $10^{4}-10^{8}$ \\
\hline TM7 & $0.95(0.022)$ & $3.46(0.036)$ & $>99 \%$ & $10^{3}-10^{7}$ \\
\hline TM7a & $0.99(0.0024)$ & $3.37(0.0059)$ & $>99 \%$ & $10^{2}-10^{6}$ \\
\hline
\end{tabular}

While the concentration of bacteria was more consistent (small standard deviation), the concentrations of TM7 and TM7a in oral plaque were more dynamic from patient to patient (Table 6 and Figure 5). Bacteria concentration ranged from $4.84 \times 10^{10}$ cells $\mathrm{g}^{-1}$ (Patient DXD) to $5.08 \times 10^{9}$ cells $\mathrm{g}^{-1}$ (Patient KPM) with an overall average of $2.26 \times 10^{10} \pm 9.24 \times 10^{9}($ mean \pm s.e.m.; $n=6)$ cells g ${ }^{-1}$ (Figure 5). TM7 counts ranged from $3.36 \times 10^{8}$ cells g ${ }^{-1}$ (Patient FYZ) to $1.08 \times 10^{7}$ cells $\mathrm{g}^{-1}$ (Patient ETP) with an overall average of $1.78 \times 10^{8} \pm 9.21 \times 10^{6}(n=6)$ cells $g^{-1}$ (Figure 5). TM7a counts ranged from $1.39 \times 10^{8}$ (Patient DXD) to $5.10 \times 10^{4}$ (Patient JNW) with an overall average of $3.36 \times 10^{7} \pm$ $2.53 \times 10^{6}(n=6)$ cells $\mathrm{g}^{-1}$ (Figure 5). 


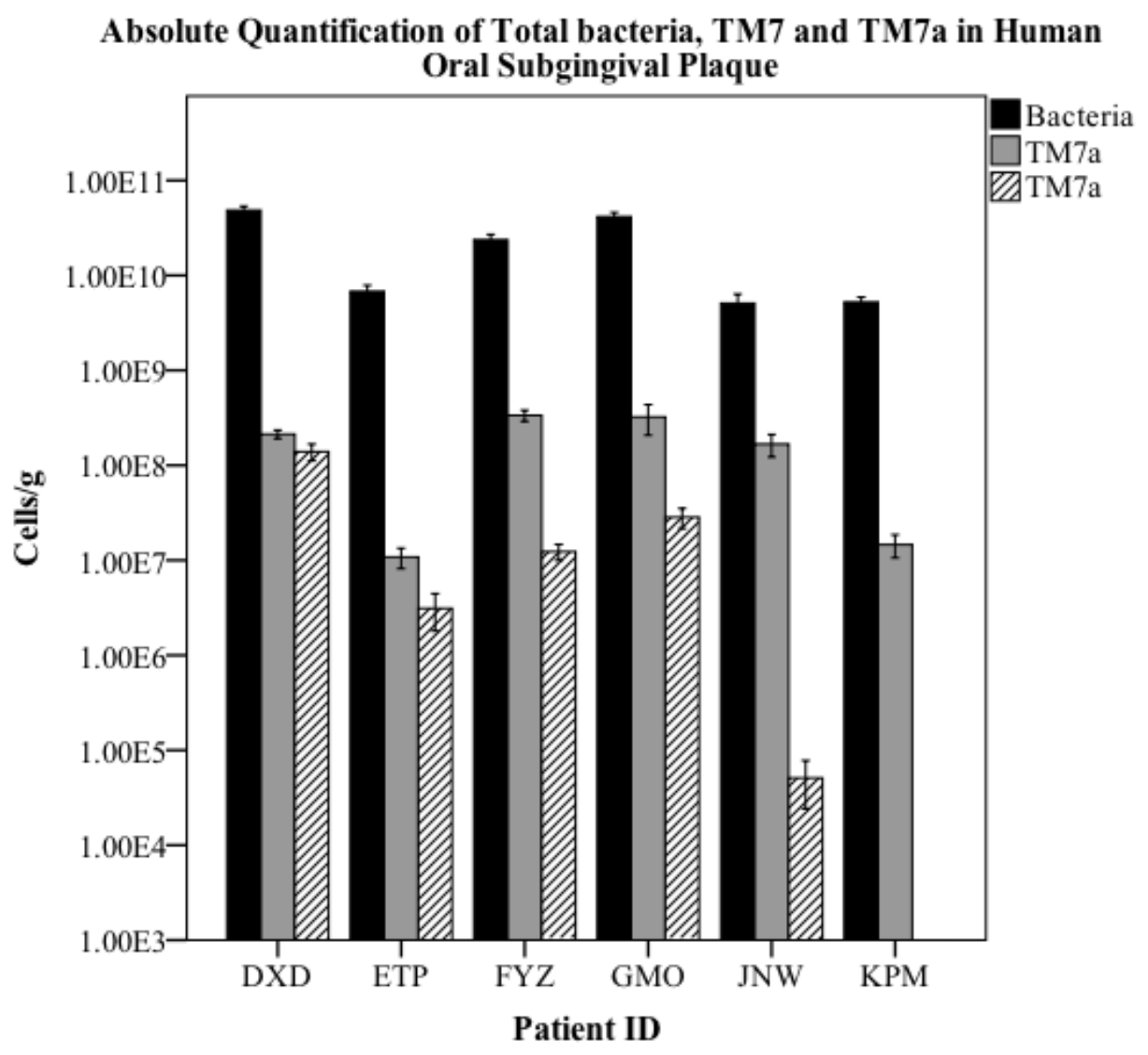

Error Bars: +/- $1 \mathrm{SE}$

Figure 5. Average number of total bacteria, TM7, and TM7a, in human oral subgingival plaque. Values represent the mean of all sampled teeth within the patient. 
To understand if the concentrations of bacteria influence the total TM7 or TM7a populations, the relative abundance of TM7 and TM7a was calculated. In other words, the concentrations of TM7 and TM7a were normalized to the total Bacteria concentration. In addition, TM7a was normalized to the total TM7 concentration. The average relative abundance of TM7 (average TM7/average bacteria) was $1.06 \% \pm 0.025 \%(n=32)$ with a range of $3.29 \% \pm 1.58 \%$ (Patient JNW; $n=5$ ) to $0.16 \% \pm 0.10 \%$ (Patient ETP; $n=6$ ) (Table 6). The average relative abundance of TM7a to bacteria (average TM7a/average bacteria) was $7.59 \times 10^{-2} \% \pm 3.08 \times 10^{-2} \%(n=22)$ and to TM7 (average TM7a/average TM7) $18.19 \% \pm 6.68 \%$ (Table 6 ). The range of TM7a to bacteria was $2.88 \times 10^{-1} \% \pm$ $2.16 \times 10^{-1} \%$ (Patient DXD; $n=6$ ) to $1.00 \times 10^{-3} \% \pm 8.65 \times 10^{-4} \%$ (Patient JNW; $n=5$ ), and to TM7 was $65.27 \% \pm 51.58 \%$ (Patient DXD; $n=6)$ to $3.05 \times 10^{-2} \% \pm 2.69 \times 10^{-2} \%$ (Patient JNW; $n=5$ ) (Table 6). 
Table 6. Quantification and relative abundance of TM7a based on qPCR assay.

Percentage of TM7a from bacteria calculated as average TM7a (cells $\mathrm{g}^{-1}$ )/average bacteria (cells $\mathrm{g}^{-1}$ ). Percentage of TM7a of TM7 calculated as average TM7a $\left(\right.$ cells g $\left.^{-1}\right)$ /average TM7 (cells g $\left.{ }^{-1}\right)$.

\begin{tabular}{|c|c|c|c|c|c|c|}
\hline & \multicolumn{6}{|c|}{ Patient ID } \\
\hline & DXD & ETP & FYZ & GMO & JNW & KPM \\
\hline $\begin{array}{c}\text { TM7a } \\
\text { Cells/g } \\
\text { Human } \\
\text { Oral } \\
\text { Plaque } \\
\text { ( } \pm \text { S.E.M.) }\end{array}$ & $\begin{array}{r}1.39 \times 10^{8} \\
\left(2.74 \times 10^{7}\right)\end{array}$ & $\begin{array}{c}3.12 \times 10^{6} \\
\left(1.32 \times 10^{6}\right)\end{array}$ & $\begin{array}{c}1.23 \times 10^{7} \\
\left(2.33 \times 10^{6}\right)\end{array}$ & $\begin{array}{c}2.84 \times 10^{7} \\
\left(6.77 \times 10^{6}\right)\end{array}$ & $\begin{array}{r}5.10 \times 10^{4} \\
\left(2.68 \times 10^{4}\right)\end{array}$ & 0 \\
\hline $\begin{array}{c}\text { Percent } \\
\text { TM7a of } \\
\text { Total } \\
\text { Bacteria } \\
\text { Population } \\
\text { ( } \pm \text { S.E.M. })\end{array}$ & $\begin{array}{c}2.88 \times 10^{-1} \% \\
\left(2.16 \times 10^{-1} \%\right)\end{array}$ & $\begin{array}{c}4.61 \times 10^{-2} \% \\
\left(4.90 \times 10^{-2} \%\right)\end{array}$ & $\begin{array}{c}5.20 \times 10^{-2} \% \\
\left(2.86 \times 10^{-2} \%\right)\end{array}$ & $\begin{array}{c}6.83 \times 10^{-2} \% \\
\left(6.02 \times 10^{-2} \%\right)\end{array}$ & $\begin{array}{c}1.00 \times 10^{-3} \% \\
\left(8.65 \times 10^{-4} \%\right)\end{array}$ & $0 \%$ \\
\hline $\begin{array}{c}\text { Percent } \\
\text { TM7a of } \\
\text { Total TM7 } \\
\text { Population } \\
\text { ( } \pm \text { S.E.M.) }\end{array}$ & $\begin{array}{c}65.27 \% \\
(51.58 \%)\end{array}$ & $\begin{array}{c}28.92 \% \\
(20.64 \%)\end{array}$ & $\begin{array}{c}3.67 \% \\
(2.12 \%)\end{array}$ & $\begin{array}{c}8.81 \% \\
(2.42 \%)\end{array}$ & $\begin{array}{c}3.05 \times 10^{-2} \% \\
\left(2.69 \times 10^{-2} \%\right)\end{array}$ & $0 \%$ \\
\hline
\end{tabular}


TM7 bacteria were present in all patients and in 32 of 34 (94.1\%) samples, suggesting TM7 is ubiquitous in the human oral cavity; however, a larger sample size would be needed to confirm such finding. TM7a populations on the one hand, were not prevalent in all samples or patients, and the abundance of total bacteria or total TM7 did not influence the abundance of TM7a. There was, however, a statistically significant difference in mean TM7a abundance between $(p<0.0005, t=4.256, n=34)$ facial sites $\left(5.15 \times 10^{7} \pm 9.49 \times 10^{6} ; n=19\right)$ and lingual sites $\left(9.78 \times 10^{6} \pm 2.01 \times 10^{6} ; n=15\right)$ (Figure 6). TM7a was $\sim 5.3$ times more abundant in sites facing the human cheeks than sites facing the tongue. TM7a was also significantly more abundant $(p<0.05, t=2.162, n=34)$ in posterior sites $\left(3.95 \times 10^{7} \pm 7.90 \times 10^{6} ; n=23\right)$ than in anterior sites $\left(2.00 \times 10^{7} \pm 4.36 \times 10^{6} ; n\right.$ $=11)$ (Figure 7). TM7a was $\sim 2$ times more abundant in the front of the mouth as compared to the back. There was no observed statistical significance regarding the abundance of TM7a between healthy $\left(3.70 \times 10^{7} \pm 6.39 \times 10^{6} ; n=30\right)$ and gingival sites $\left(8.12 \times 10^{6} \pm 2.72 \times 10^{6} ; n=4\right)$ (Figure 8), even though TM7a was found to be $\sim 4.5$ times more abundant in healthy sites. Suggesting that there are other unidentified factors influencing the abundance and prevalence of TM7a in subgingival plaque. 


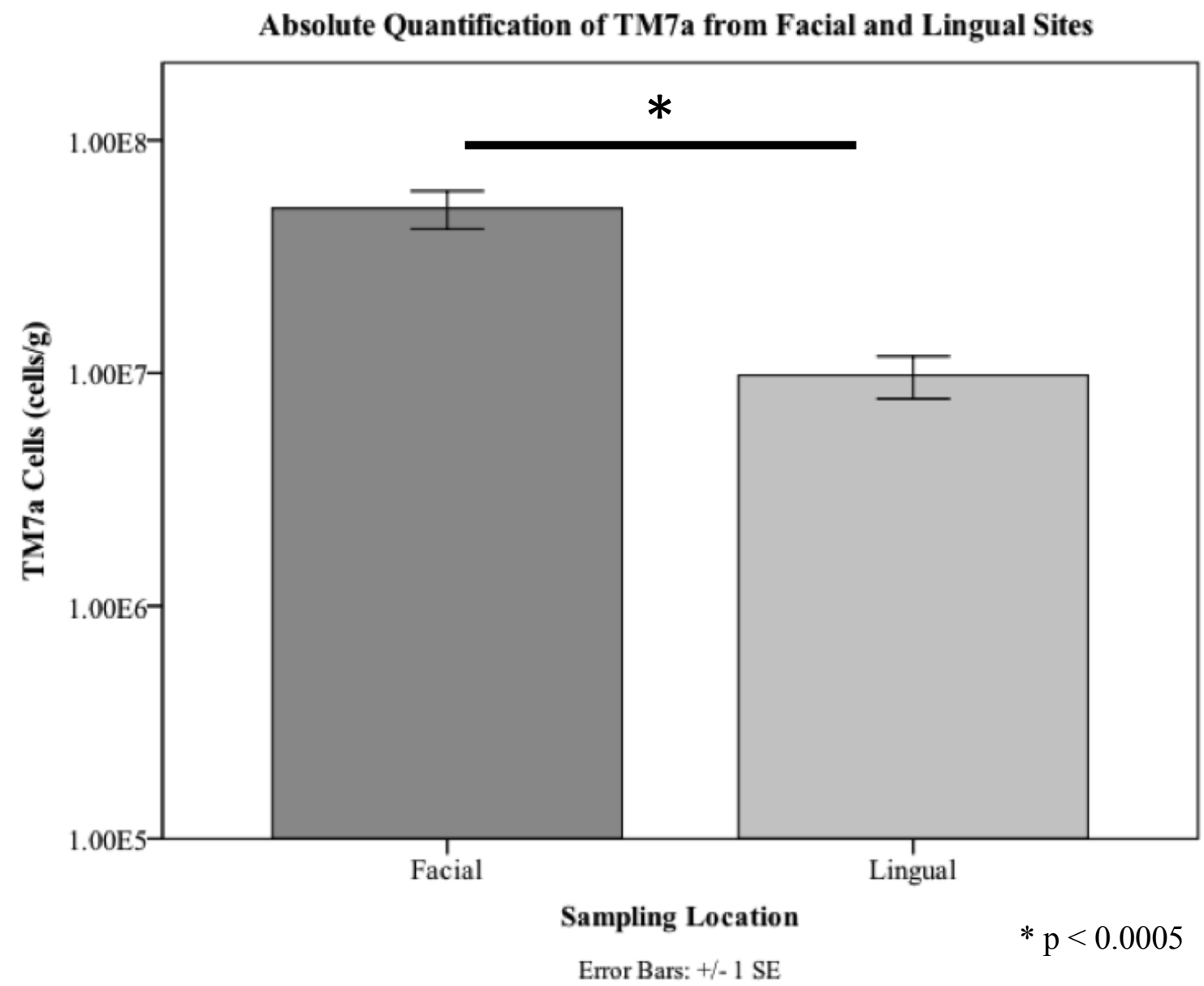

Figure 6. Average number (cells $\mathrm{g}^{-1}$ ) of TM7a cells from facial and lingual plaque samples. 


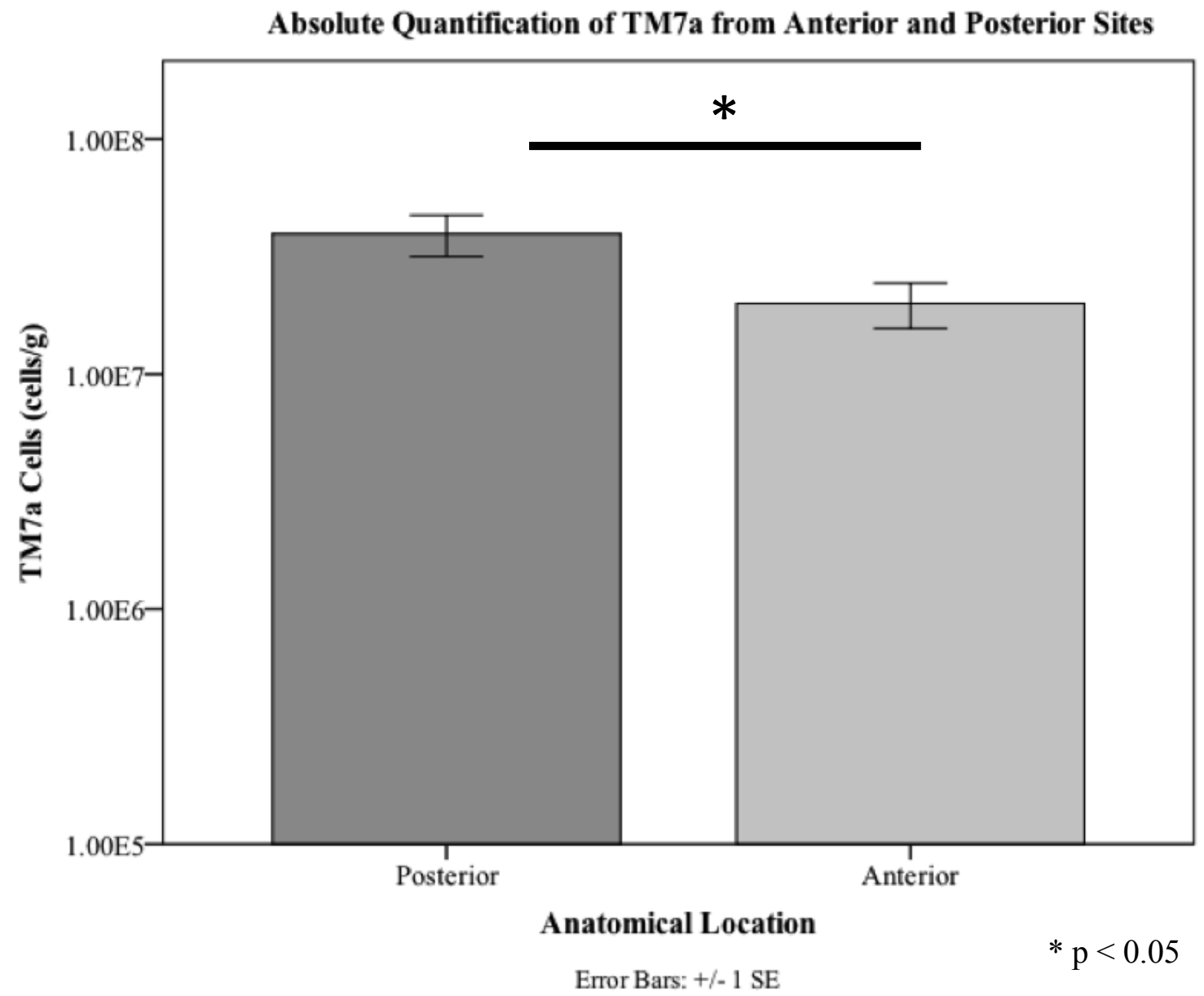

Figure 7. Average number of TM7a cells (cells $\mathrm{g}^{-1}$ ) from anterior or posterior plaque samples. 


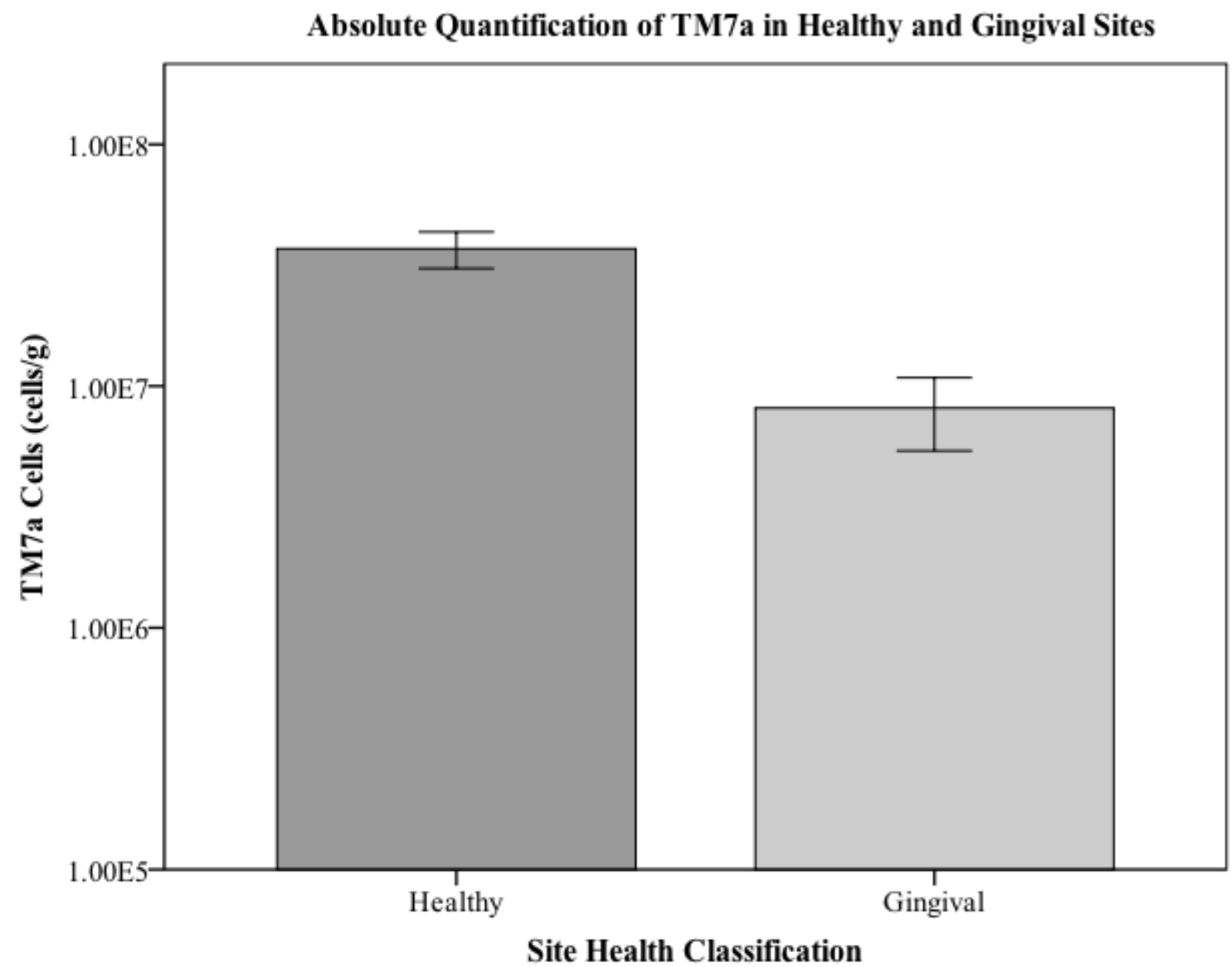

Error Bars: +/- $1 \mathrm{SE}$

Figure 8. Average number of TM7a cells $\left(\right.$ cells $\mathrm{g}^{-1}$ ) from Healthy or Gingival plaque samples. Health status determined by depth of periodontal pocket, classified as either healthy $(\mathrm{PD} \leq 3)$ or gingival $(\mathrm{PD} \geq 4)$. 


\section{Discussion}

\section{Assay to Target TM7a in Human Subgingival Plaque}

TM7a has been detected in both environmental and human sites. However, it has only been quantified in activated wastewater and not in human samples. In this study, the first quantification of TM7a in human oral plaque samples was performed. The environmental TM7a from wastewater has been named "TM7a-like" by its founders (Dinis et al. 2011). The qPCR TaqMan assay to Target TM7a-like in activated wastewater used two primers (TM7a 997F and TM7a-like 1112R) plus one fluorescent probe (TM7a 1033). In this study the same forward primer (TM7a 997F) and probe (TM7a 1033) as in Dinis et al. (2011) was used, but also a broad range TM7 reverse primer (TM7 1177R), which targets both TM7a and "TM7a-like" bacteria. In addition, the qPCR assay used in this study, detects 25 TM7a phylotypes as compared to 20 TM7 phylotypes detected with the reverse primer used in the Dinis et al. (2011) qPCR assay. This $25 \%$ increase in detection power to the qPCR assay can be significant if the proportion of the 5 newly detected TM7 phylotypes are predominant members in a particular sample site. 


\section{Quantification of TM7 and TM7a in Human Subgingival Plaque}

TM7 bacteria were present in all patients and in 32 of 34 (94.1\%) samples. This is consistent with a previous study surveying TM7 in human subgingival plaque, which detected TM7 in 86 of 90 (96\%) samples (Brinig et al. 2003). Results suggest the division TM7 is common in the human oral cavity and perhaps even a permanent resident. TM7a on the other hand, was detected in 5 of $6(83 \%)$ patients and in 22 of $34(64.7 \%)$ samples. The only previous quantification of TM7a was performed in activated wastewater (Dinis et al. 2011), which found "TM7a-like" in 4 of 23 (17.4\%) samples, suggesting that the factors that contribute to the prevalence of TM7a may differ from other TM7 bacteria.

The relative abundance of TM7 (average TM7/ average bacteria) from human subgingival plaque in this study was $1.06 \% \pm 0.025 \%(\mathrm{SE})$, as compared to the previous study by Brinig et al. (2003), which found TM7 to make up $0.3 \%$ of the total bacteria community by real-time PCR. Although the relative abundance of TM7 in this study is $253 \%$ greater than found by Brinig et al. (2003), it is important to note the percentage of TM7 in the previous study was calculated based on the total rRNA copy number/ $\mu$, which did not take into account the normalization of average rRNA gene copy found in the TM7 and bacteria genomes (see figure 3) as performed in this study, and is therefore likely underestimated. The TM7 gene copy number was not available until 2007 (Marcy et al. 2007), three years after the first TM7 qPCR quantification by Brinig et al. (2003) was published. 
The relative abundance of TM7a to bacteria (average TM7a/average bacteria) in this study was $7.59 \times 10^{-2} \% \pm 3.08 \times 10^{-2} \%$ and to TM7 (average TM7a/average TM7) $18.19 \% \pm 6.68 \%$. TM7a has not been quantified in human oral samples, but based on the previous quantification of TM7a in activated wastewater (Dinis et al. 2011), "TM7a-like" was found to make up $0.01 \%$ of total bacteria and $0.44 \%$ of TM7. Although this is a pilot study, these limited data suggests that TM7a is present in greater percentage in subgingival plaque than in activated wastewater.

Consistent with other studies, there was no correlation between the abundance of TM7 and gender, smoking status, or age (Brinig et al. 2003). TM7a on the one hand was found to be significantly more abundant in posterior than anterior sites, as well as significantly more abundant in facial than lingual sites. It is unknown as to what the contributing factors are that favor TM7a preference for these locations; however, an indepth look at the total bacterial composition at these sites may shed some light on the matter. TM7a was also found to be more abundant in healthy samples; however, this finding was not statistically significant and is consistent with the previous study (Brinig et al. 2003) that found TM7 to be more abundant in gingival sites, but not statistically significant. Both this study and the one performed by Brinig et al. (2003) had relatively small populations of gingival samples, 4 of $34(11.8 \%)$ and 5 of $76(6.6 \%)$, respectively. Perhaps with a larger sample size, the significance of TM7 and TM7a at these sites can be elucidated. 


\section{Future Directions}

The overall abundance of TM7 and TM7a were dynamic in human subgingival plaque. Although the presence of TM7 was more consistent, the same could not be said about TM7a. There are many factors, which can contribute to their prevalence including diet, health, and the bacterial composition at each site. A future cross-sectional study quantifying TM7a in a more diverse population could provide more details on TM7a prevalence. Next-generation sequencing can identify the bacterial population from each sample and may reveal trends that favor the prevalence of TM7 and TM7a in human subgingival plaque.

In addition, a temporal study utilizing both a quantitative analysis and nextgeneration sequencing can provide a glimpse of how the bacterial population changes, and how these changes reflect on the abundance and overall prevalence of TM7 and TM7a at each site.

\section{Conclusions}

In this pilot study, TM7a was successfully detected and quantified in human subgingival plaque. Consistent with previous studies, TM7 was not found to be significantly more abundant in gingival samples as compared to healthy samples. TM7a on the other hand was found to be significantly more abundant in facial sites as well as posterior sites as compared to lingual sites and anterior sites respectively. A larger and 
more diverse sample size, including a wider array of diseased samples is needed to make correlations between TM7a and human oral disease. Here we presented an optimized assay that successfully quantified TM7a in human oral sites. 


\section{References}

Albertsen, M., Hugenholtz, P., Skarshewski, A., Nielsen, K., Tyson, G., and Nielsen, P. (2013). Genome sequences of rare, uncultured bacteria obtained by different coverage binning of multiple metagenomes. Nature Biotechnol. 31, 533-538.

Altschul, S.F., Madden, T.L., Schäffer, A.A., Zhang, J., Zhang, Z., Miller, W., and Lipman, D.J. (1997). Gapped BLAST and PSI-BLAST: a new generation of protein database search programs. Nucleic Acids Res. 25, 3389-3402.

Amann, R.I., Ludwig, W., and Schleifer, K.H. (1995). Phylogenetic identification and in situ detection of individual microbial cells without cultivation. Microbiol. Rev. 59, 143-169.

Applied Biosystems (2005). Absolute quantification getting started guide for the applied biosystems 7300/7500/7500 fast real-time PCR system (Rev. D). Foster City, California: Applied Biosystems.

Brinig, M.M., Lepp, P.W., Ouverney, C.C., Armitage, G.C., and Relman, D.A. (2003). Prevalence of bacteria of division TM7 in human subgingival plaque and their association with disease. Appl. Environ. Microbiol. 69, 1687-1694.

Cole, J.R., Chai, B., Marsh, T.L., Farris, R.J., Wang, Q., Kulam, S., Chandra, S., McGarrell, D., Schmidt, T.M., and Garrity, G.M. (2003). The Ribosomal Database Project (RDP-II): previewing a new autoaligner that allows regular updates and the new prokaryotic taxonomy. Nucleic Acids Res. 31, 442-443.

DeLong, E.F. (1992). Archaea in coastal marine environments. PNAS. 89, 5685-5689.

Dental Implants USA. Tooth orientation chart. Retrieved, June 6, 2013, from http://www.dentalimplants-usa.com

DeSantis Jr, T., Hugenholtz, P., Keller, K., Brodie, E., Larsen, N., Piceno, Y., Phan, R., and Andersen, G. (2006). NAST: a multiple sequence alignment server for comparative analysis of 16S rRNA genes. Nucleic Acids Res. 34, W394-W399.

DeSantis, T.Z., Hugenholtz, P., Larsen, N., Rojas, M., Brodie, E.L., Keller, K., Huber, T., Dalevi, D., Hu, P., and Andersen, G.L. (2006). Greengenes, a chimera-checked 16S rRNA gene database and workbench compatible with ARB. Appl. Environ. Microbiol. 72, 5069-5072. 
Dewhirst FE, Chen T, Izard J, Paster BJ, Tanner AC, et al. (2010) The human oral microbiome. J. Bacteriol. 192, 5002-5017

Dewhirst, F.E., Klein, E.A., Thompson, E.C., Blanton, J.M., Chen, T., Milella, L., Buckley, C.M.F., Davis, I.J., Bennett, M.L., and Marshall-Jones, Z.V. (2012). The canine oral microbiome. PloS One. 7, e36067.

Dinis, J.M., Barton, D.E., Ghadiri, J., Surendar, D., Reddy, K., Velasquez, F., Chaffee, C.L., Lee, M.C.W., Gavrilova, H., Ozuna, H., et. al. (2011). In search of an uncultured human-associated TM7 bacterium in the environment. PloS One. 6 , e21280.

Fredricks, D.N., Fiedler, T.L., Thomas, K.K., Oakley, B.B., and Marrazzo, J.M. (2007). Targeted PCR for detection of vaginal bacteria associated with bacterial vaginosis. J. Clin. Microbiol. 45, 3270-3276.

Gao, Z., Tseng, C., Pei, Z., and Blaser, M.J. (2007). Molecular analysis of human forearm superficial skin bacterial biota. PNAS. 104, 2927-2932.

Guss, A.M., Roeselers, G., Newton, I.L.G., Young, C.R., Klepac-Ceraj, V., Lory, S., and Cavanaugh, C.M. (2010). Phylogenetic and metabolic diversity of bacteria associated with cystic fibrosis. ISME J. 5, 20-29.

Hardoim, C., Costa, R., Araujo, F., Hajdu, E., Peixoto, R., Lins, U., Rosado, A., and Van Elsas, J. (2009). Diversity of bacteria in the marine sponge Aplysina fulva in Brazilian coastal waters. Appl. Environ. Microbiol. 75, 3331-3343.

Hugenholtz, P., Goebel, B.M., and Pace, N.R. (1998). Impact of culture-independent studies on the emerging phylogenetic view of bacterial diversity. J. Bacteriol. 180, 4765-4774.

Hugenholtz, P., Tyson, G.W., and Blackall, L.L. (2002). Design and evaluation of 16S rRNA-targeted oligonucleotide probes for fluorescence in situ hybridization. Methods. Mol. Biol. 179, 29-42.

Hugenholtz, P., Tyson, G.W., Webb, R.I., Wagner, A.M., and Blackall, L.L. (2001). Investigation of candidate division TM7, a recently recognized major lineage of the domain Bacteria with no known pure-culture representatives. Appl. Environ. Microbiol. 67, 411-419.

Kuehbacher, T., Rehman, A., Lepage, P., Hellmig, S., Fölsch, U.R., Schreiber, S., and Ott, S.J. (2008). Intestinal TM7 bacterial phylogenies in active inflammatory bowel disease. J. Med. Microbiol. 57, 1569-1576. 
Kumar, P., Griffen, A., Barton, J., Paster, B., Moeschberger, M., and Leys, E. (2003). New bacterial species associated with chronic periodontitis. J. Dent. Res. 82, 338344.

Lane, D. (1991). 16/23S rRNA sequencing. Nuc. Acid Tech. Bacterial Sys. 115 - 175.

Lawson, A.J., Linton, D., and Stanley, J. (1998). 16S rRNA gene sequences of 'Candidatus Campylobacter hominis', a novel uncultivated species, are found in the gastrointestinal tract of healthy humans. Microbiol. 144, 2063-2071.

Lewis, K., Epstein, S., D'Onofrio, A., and Ling, L.L. (2010). Uncultured microorganisms as a source of secondary metabolites. J. Antibiot. 63, 468-476.

Liu, B., Faller, L.L., Klitgord, N., Mazumdar, V., Ghodsi, M., Sommer, D.D., Gibbons, T.R., Treangen, T.J., Chang, Y.C., and Li, S. (2012). Deep Sequencing of the Oral Microbiome Reveals Signatures of Periodontal Disease. PloS One. 7, e37919.

Ludwig, W., Strunk, O., Westram, R., Richter, L., Meier, H., Buchner, A., Lai, T., Steppi, S., Jobb, G., and Förster, W. (2004). ARB: a software environment for sequence data. Nuc. Acid Res. 32, 1363-1371.

Marcy, Y., Ouverney, C., Bik, E.M., Lösekann, T., Ivanova, N., Martin, H.G., Szeto, E., Platt, D., Hugenholtz, P., and Relman, D.A. (2007). Dissecting biological "dark matter" with single-cell genetic analysis of rare and uncultivated TM7 microbes from the human mouth. PNAS. 104, 11889-11894.

Mckenzie, H.A., and White, F.H. (1991). Lysozyme and $\alpha$-lactalbumin: structure, function, and interrelationships. Adv. Protein Chem. 41, 173-315.

National Institute of Dental and Craniofacial Research. Use of Probe to Measure Periodontal Pocket Depth. Retrieved, June 11, 2013 from http://www.nidcr.nih.gov

Oliver, R., Brown, L., and Loe, H. (1991). Variations in the prevalence and extent of periodontitis. JADA. 122, 43-48.

Ouverney, C.C., Armitage, G.C., and Relman, D.A. (2003). Single-cell enumeration of an uncultivated TM7 subgroup in the human subgingival crevice. Appl. Environ. Microbiol. 69, 6294-6298.

Paster, B.J., Boches, S.K., Galvin, J.L., Ericson, R.E., Lau, C.N., Levanos, V.A., Sahasrabudhe, A., and Dewhirst, F.E. (2001). Bacterial diversity in human subgingival plaque. J. Bacteriol. 183, 3770-3783. 
Pei, Z., Bini, E.J., Yang, L., Zhou, M., Francois, F., and Blaser, M.J. (2004). Bacterial biota in the human distal esophagus. PNAS. 4250-4255.

Podar, M., Abulencia, C.B., Walcher, M., Hutchison, D., Zengler, K., Garcia, J.A., Holland, T., Cotton, D., Hauser, L., and Keller, M. (2007). Targeted access to the genomes of low-abundance organisms in complex microbial communities. Appl. Environ. Microbiol. 73, 3205-3214.

Rappé, M.S., and Giovannoni, S.J. (2003). The uncultured microbial majority. Annu. Rev Microbiol. 57, 369-394.

Schmidt, T., and Konopka, A. (2009). Physiological and ecological adaptations of slowgrowing, heterotrophic microbes and consequences for cultivation. Uncultivated Microorganisms. 257-276.

Sogin, M. (2009). Characterizing microbial population structures through massively parallel sequencing. Uncultivated Microorganisms. 19-33.

Woese, C.R. (1987). Bacterial evolution. Microbiol. 51, 221.

Yeates, C., Gillings, M., Davison, A., Altavilla, N., and Veal, D. (2003). PCR amplification of crude microbial DNA extracted from soil. Lett. Appl. Microbiol. 25, 303-307. 